\title{
FGFR signaling regulates resistance of head and neckearch Paper stem cells to cisplatin
}

\author{
Sarah C. McDermott ${ }^{1}$, Christie Rodriguez-Ramirez ${ }^{2}$, Sean P. McDermott ${ }^{3}$, Max S. \\ Wicha $^{3}$ and Jacques E. Nör ${ }^{2,4,5}$ \\ ${ }^{1}$ Department of Orthodontics and Pediatric Dentistry, University of Michigan School of Dentistry, Ann Arbor, MI, USA \\ ${ }^{2}$ Department of Cariology, Restorative Science \& Endodontics, University of Michigan School of Dentistry, Ann Arbor, MI, USA \\ ${ }^{3}$ Department of Internal Medicine-Hematology/Oncology, University of Michigan Medical School, Ann Arbor, MI, USA \\ ${ }^{4}$ Department of Biomedical Engineering, University of Michigan College of Engineering, Ann Arbor, MI, USA \\ ${ }^{5}$ Department of Otolaryngology, University of Michigan Medical School, Ann Arbor, MI, USA \\ Correspondence to: Jacques E. Nör, email: jenor@umich.edu \\ Keywords: chemotherapy; microarray; chemoresistance; head and neck squamous cell carcinoma; tumor-initiating cells \\ Received: November 03, $2017 \quad$ Accepted: April 25, $2018 \quad$ Published: May 18, 2018 \\ Copyright: McDermott et al. This is an open-access article distributed under the terms of the Creative Commons Attribution License \\ 3.0 (CC BY 3.0), which permits unrestricted use, distribution, and reproduction in any medium, provided the original author and \\ source are credited.
}

\section{ABSTRACT}

Patients with recurrent or metastatic head and neck squamous cell carcinoma (HNSCC) have poor prognosis with less than 1-year median survival. Platinumbased chemotherapy remains the first-line treatment for HNSCC. The cancer stem cell (CSC) hypothesis postulates that tumors are maintained by a self-renewing CSC population that is also capable of differentiating into non-self renewing cell populations that constitute the bulk of the tumor. A small population of CSC exists within HNSCC that are relatively resistant to chemotherapy and clinically predicted to contribute to tumor recurrence. These head and neck CSCs (HNCSC) are identified by high cell-surface expression of CD44 and high intracellular activity of aldehyde dehydrogenase (ALDH) and termed ALDH ${ }^{\text {high }}$ CD44 ${ }^{\text {high }}$. Here, we performed microarray analysis in two HNSCC cell lines (UM-SCC-1, UM-SCC-22B) to investigate molecular pathways active in untreated and cisplatin-resistant $A_{L D H}{ }^{\text {high }} C D 44^{\text {high }}$ cells. Gene set enrichment analysis and iPathway analysis identified signaling pathways with major implications to the pathobiology of cancer (e.g. TNFa, IFN, IL6/STAT, NF-KB) that are enriched in cisplatin-resistant ALDH ${ }^{\text {high }}$ CD44 ${ }^{\text {high }}$ cells, when compared to control cells. FGF2 was also enriched in cisplatin-resistant ALDH ${ }^{\text {high }}$ CD44 ${ }^{\text {high }}$, which was confirmed by ELISA analysis. Inhibition of FGF signaling using BGJ398, a panFGF receptor (FGFR) small-molecule inhibitor, decreased $A L D H^{\text {high }}$ CD44 ${ }^{\text {high }}$ alone in UM-SCC-1 and preferentially targeted cisplatin-resistant ALDH ${ }^{\text {high }}$ CD44 ${ }^{\text {high }}$ cells in UMSCC-22B. These findings suggest that FGFR signaling might play an important role in the resistance of head and neck CSC to cisplatin. Collectively, this work suggests that some head and neck cancer patients might benefit from the combination of cisplatin and a FGFR inhibitor.

\section{INTRODUCTION}

Conventional wisdom in cancer treatment considers mass reduction the standard for evaluating success. Less thought is given to underlying tumor cell heterogeneity, yet several recent studies have found significant heterogeneity among tumor cells [1-4]. The discrepancy between treatments designed to treat tumor cells as a single population and the finding of tumor cell heterogeneity may explain the considerably small decrease in overall cancer death rate $(<5 \%)$, despite over $\$ 200$ billion invested in cancer research since 1970. In the 
US, 59,340 new cases and 12,290 deaths from head and neck squamous cell carcinoma (HNSCC) are estimated in 2015 [5]. At diagnosis, 31\% of cases are localized, 47\% are regional, and $18 \%$ are distant. The 5-year relative survival rate, based on data from 2004-2010, for cancers in the oral cavity and pharynx is $66 \%$ for all races, but only $45 \%$ for African-Americans. The 5-year survival rate for patients presenting at diagnosis with distant disease is only $37 \%$ compared to $85 \%$ for localized and $61 \%$ for regional disease [5]. Furthermore, the median survival for patients with recurrent or metastatic HNSCC remains less than one year [6].

Platinum-based chemotherapy, cisplatin or carboplatin, is the typical first-line treatment for recurrent or metastatic HNSCC and cisplatin is typically combined with fluorouracil [6]. HNSCC can express the epidermal growth factor receptor (EGFR) and is associated with poor outcome [7]. Cetuximab, an IgG1 monoclonal antibody, inhibits ligand binding to EGFR [8] and stimulates antibody-dependent cell-mediated cytotoxicity [9]. The EXTREME study demonstrated the benefit of adding cetuximab to chemotherapy and was the first phase III trial in recurrent or metastatic HNSCC to improve overall survival since cisplatin was introduced [10]. Overall survival increased from 7.4 months with only chemotherapy to 10.1 months with chemotherapy plus cetuximab. Cetuximab is the only FDA-approved molecularly targeted therapeutic approved for HNSCC. Clearly, additional therapies are needed to improve the prognosis of patients with HNSCC.

In a traditional stochastic model of cancer, any cancer cell may reform or regrow the entirety of a tumor. The cancer stem cell (CSC) hypothesis postulates that tumors are maintained by a small self-renewing CSC population that is also capable of differentiating into non-self renewing cell populations that constitute the bulk of the tumor [11]. The ability of CSCs to generate progenitor cells, cells with decreased self-renewal capacity, ultimately generates heterogeneity within the tumor. Clinically, CSCs are predicted to mediate tumor recurrence after chemotherapy and radiation-therapy due to the relative inability of these modalities to effectively target CSCs [12]. By eliminating the CSCs through targeted therapy, we may cause natural cancer regression through loss of growth potential. Without targeted therapy, cancer relapse will occur through CSC division and proliferation [12]. Therefore, new therapies that target CSCs must be developed and combined with standard therapy to achieve a true cure.

In 2007, Prince and colleagues first reported the existence of a subpopulation of HNSCC cells, isolated by expression of the cell-surface protein CD44, in primary tumor samples [4]. Similar to other CSCs, these cells exhibited stem cell like properties of self-renewal, tumorigenesis, and differentiation into non-CSCs. Clinically, high frequency of CD44+ cells was associated with tumor grade and poor outcome [13]. Subsequent studies showed HNCSCs could be identified by expression of CD133 [14] and intracellular aldehyde dehydrogenase (ALDH) activity $[15,16]$. HNCSCs can be identified by dual expression of $\mathrm{ALDH}^{\text {high }}$ and CD44 ${ }^{\text {high }}$, but not all $\mathrm{ALDH}^{\text {high }} \mathrm{CD} 44^{\text {high }}$ cells exhibit CSC activity $[17,18]$. Regional and distant metastases in HNSCC correspond to poor prognosis and treatment options. CSCs are often hypothesized to be the origin of metastases, and as such, in vitro and in vivo work has shown HNSCC CD44 ${ }^{\text {high }}$ cells have more migration, invasion and metastatic ability as compared to CD44 ${ }^{\text {low }}$ cells [19]. HNCSCs were shown to be enriched after cisplatin or 5-FU treatment $[20,21]$, which is consistent with the presumed role of CSCs in mediating resistance to chemotherapy. Despite the important advancements in identifying HNCSCs, very little information exists about the molecular pathways active in HNCSCs [16], let alone the mechanisms that govern chemotherapy resistance of HNCSCs.

To facilitate the development of targeted therapies to eradicate HNCSCs, there exists a need for greater insight into the mechanisms that govern chemotherapy resistance of HNCSC. Here, we isolated cisplatin-resistant HNCSCs from a HNSCC cell line, identified pathways active in cisplatin-resistant HNCSCs by using microarray analysis, and then investigated the role of a candidate gene, FGF2, in resistance of HNCSCs to chemotherapy. These results provide a rich microarray resource of naïve and cisplatin HNCSCs and suggest that targeting FGF signaling in combination with cisplatin may eradicate HNCSCs.

\section{RESULTS}

To understand the chemotherapy resistance mechanisms of $\mathrm{ALDH}^{\text {high }} \mathrm{CD} 44^{\text {high }}$ cells in $\mathrm{HNSCC}$, we used two HNSCC cell lines, UM-SCC-1 and UM-SCC-22B [22]. UM-SCC-1 was from a primary tumor at the floor of the mouth, and UM-SCC-22B was from a neck metastasis derived from a tumor in the hypopharynx. The cisplatin $\mathrm{IC}_{50}$ for UM-SCC- 1 was $1.77 \pm 0.78 \mu \mathrm{M}$ and UM-SCC-22B was higher at $5.51 \pm 1.37 \mu \mathrm{M}$ (Supplementary Figure 1). Initial experiments to examine the resistance of $\mathrm{ALDH}{ }^{\text {high }} \mathrm{CD} 44^{\text {high }}$ cells to cisplatin at the $\mathrm{IC}_{50}$ concentrations were highly variable (data not shown). Based on published reports [21], we utilized $2 \mu \mathrm{M}$ cisplatin for additional experiments. Additional experiments at $2 \mu \mathrm{M}$ showed maximal enrichment of $\mathrm{ALDH}{ }^{\text {high }} \mathrm{CD} 44^{\text {high }}$ cells in both UM-SCC-1 and UM-SCC-22B cell lines after 5 days of treatment (Figure 1, Supplementary Figures 2, 3).

To determine if $2 \mu \mathrm{M}$ cisplatin and 5 days of treatment would provide a reasonable amount of gene expression changes, we initiated a pilot microarray experiment with UM-SCC-22B to test if it was possible to obtain a sufficient number of cells from flow cytometry sorting. ALDH ${ }^{\text {high }} \mathrm{CD} 44^{\text {high }}$ and $\mathrm{ALDH}^{\text {low }} \mathrm{CD} 44^{\text {low }}$ cells from control and cisplatin treated UM-SCC-22B cells were collected. The gating schema used for collecting cells by 
flow cytometry is shown in Figure 2A. Based on probe sets with a fold change of 2 or more with the added constraint that one of the two samples had an expression value of $2^{4}$ or greater, there were 234 probe sets differing between cisplatin $\mathrm{ALDH} \mathrm{H}^{\text {high }} \mathrm{CD} 44^{\text {high }}$ and control $\mathrm{ALDH}{ }^{\text {high }} \mathrm{CD} 44^{\text {high }}$ cells. FGF2, EREG (epiregulin), AREG (amphiregulin), and SPRR1B (small proline-rich protein 1B) were some of the genes higher in cisplatin $\mathrm{ALDH}{ }^{\text {high }} \mathrm{CD} 44^{\text {high }}$.

In order to provide robust statistical comparison between cisplatin $\mathrm{ALDH}^{\text {high }} \mathrm{CD} 44^{\text {high }}$ and control $\mathrm{ALDH}^{\text {high }} \mathrm{CD} 44^{\text {high }}$ cells, four additional sorts of $\mathrm{ALDH}^{\text {high }} \mathrm{CD} 44^{\text {high }}$ and $\mathrm{ALDH}^{\text {low }} \mathrm{CD} 44^{\text {low }}$ populations were performed (Figure 2B-2E). In general, very few $\mathrm{ALDH}^{\text {high }} \mathrm{CD} 44^{\text {high }}$ cells were collected (Supplementary Table 1). Even though there was limiting total RNA in the $\mathrm{ALDH}^{\text {high }} \mathrm{CD} 44^{\text {high }}$ fractions (average $113 \mathrm{ng}$ ), RNA quality, as determined by Bioanalyzer analysis, ranged from 7.8 to 10.0 , which was robust enough for microarray analysis. Due to limited RNA for experiment \#4, RNA from experiments 1-3 were utilized for microarray analysis using at least $10 \mathrm{ng}$ of total RNA processed with the Ovation Pico whole transcriptome amplification kit and hybridized with Affymetrix Human Gene ST 2.1 plates.
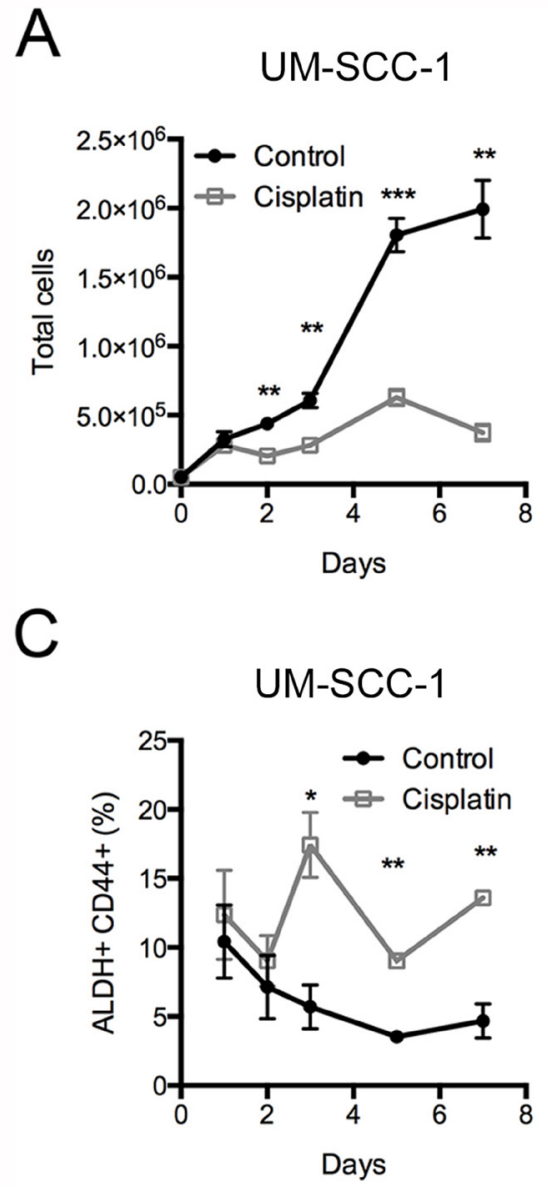

The pilot and larger microarray samples were processed with the same transcriptome kit and hybridized to the same microarray platform. We used bioinformatic analysis with $\mathrm{R}$ and Bioconductor packages to determine if the pilot and larger microarray experiments could be combined for downstream differential gene expression analysis. We utilized histogram and principal component analyses, which showed the pilot microarray samples exhibited the largest variance (Supplementary Figure 4C). To adjust for experiment batch differences, we used Combat [22], which utilizes empirical Bayes methods. After adjusting for the four experimental batches, both histogram and principal component analysis showed the four cell populations (Control $\mathrm{ALDH}{ }^{\text {high }} \mathrm{CD} 44^{\text {high }}$, Control $\mathrm{ALDH}^{\text {low }} \mathrm{CD} 44^{\text {low }}$, Cisplatin $\mathrm{ALDH}^{\text {high }} \mathrm{CD} 44^{\text {high }}$, Cisplatin ALDH ${ }^{\text {low }} \mathrm{CD} 44^{\text {low }}$ ) were grouped closer together (Figure 3A, 3B; Supplementary Figure 4D).

Differentially expressed genes were determined using univariate comparisons (e.g. Cisplatin $\mathrm{ALDH}^{\text {high }} \mathrm{CD} 44^{\text {high }}$ versus Control $\left.\mathrm{ALDH}{ }^{\text {high }} \mathrm{CD} 44^{\text {high }}\right)$ and adjusted for multiple testing comparisons. Genes with an adjusted $p$-value $<0.05$ were considered statistically significant. Since the Affymetrix Human Gene ST 2.1

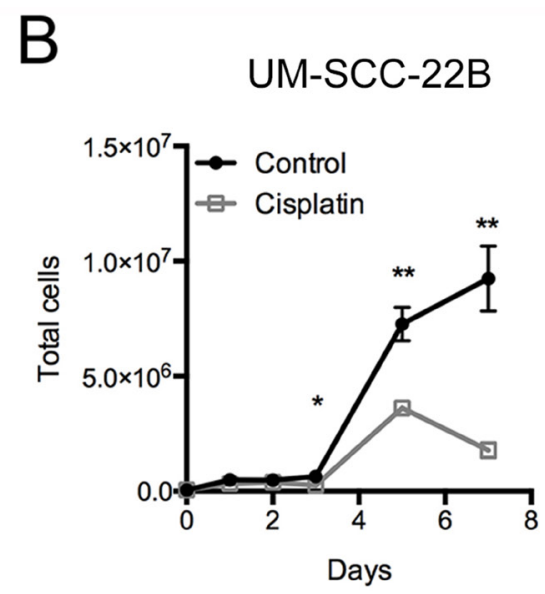

D

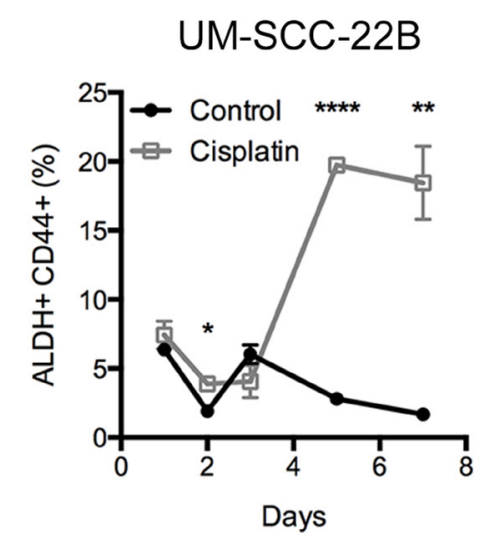

Figure 1: Frequency of $\mathbf{A L D H}{ }^{\text {high }} \mathbf{C D} 44^{\text {high }}$ cells after cisplatin treatment. UM-SCC-1 and UM-SCC-22B cells were treated with control (black circles) or $2 \mu \mathrm{M}$ cisplatin (grey open squares) for up to 7 days. The total number of cells for (A) UM-SCC-1 and (B) UM-SCC-22B. The frequency of $(\mathbf{C}, \mathbf{D}) \mathrm{ALDH}^{\text {high }} \mathrm{CD} 44^{\text {high }}$ cells based on gates from DEAB sample. 
microarrays also include microRNAs, lincRNAs, and nonannotated probes, we focused on probes annotated with Entrez ID and HUGO gene symbols. In general, there were about 200-1000 genes differentially expressed between the groups (Table 1). We combined the genes from the four-univariate comparisons and performed unsupervised hierarchical clustering (Figure 3C). As expected, the four samples within each cell population clustered together since the four experimental batches were adjusted and we only considered differentially expressed genes.

To investigate the pathways modulated in cisplatin $\mathrm{ALDH}^{\text {high }} \mathrm{CD} 44^{\text {high }}$ vs. control $\mathrm{ALDH}^{\text {high }} \mathrm{CD} 44^{\text {high }}$, we used Gene Set Enrichment Analysis (GSEA) [23]. Recently, a new set of 50 gene sets, termed 'Hallmarks', was developed. These gene sets represent specific welldefined biological states or processes and display coherent expression. The Hallmark gene sets were generated by a computational methodology based on identifying gene set overlaps and extracting coherent representatives of them. We used GSEA with the Hallmark gene sets to evaluate cisplatin $\mathrm{ALDH}^{\text {high }} \mathrm{CD} 44^{\text {high }}$ vs. control $\mathrm{ALDH}^{\text {high }} \mathrm{CD} 44^{\text {high }}$. Among the highly statistically significant gene sets enriched in cisplatin $\mathrm{ALDH}^{\text {high }} \mathrm{CD} 44^{\text {high }}$ were inflammatory signaling pathways, such as Interferon (IFN) Alpha Response (Genes up-regulated in response to IFN $\alpha$ proteins), TNF $\alpha$ Signaling Via NF- $\kappa \mathrm{B}$ (Genes regulated by NF- $\kappa \mathrm{B}$ in response to TNF), and IL6-JAK-STAT3 signaling (Genes up-regulated by IL6 via STAT3 during acute phase response) (Figure 4A-4C). Leading edge analysis of those three Hallmark pathways identified numerous genes in common, such as CXCL10, CXCL11, and IRF1 (Supplementary Table 2). Of note, only BST2, ICAM1, IL1 $\beta$, IFIT2, and IFIH1 were statistically different based on univariate analysis with FDR adjustment. Only two Hallmark gene sets were statistically enriched in
A

A

Control
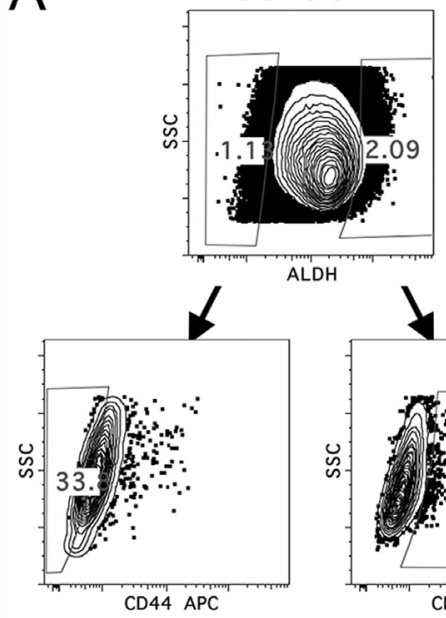

B $p=0.0004$

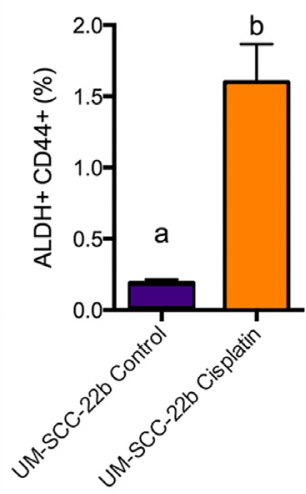

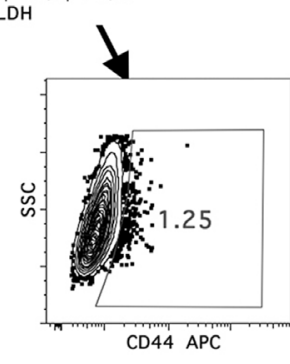

C $\quad \mathrm{p}=0.0036$

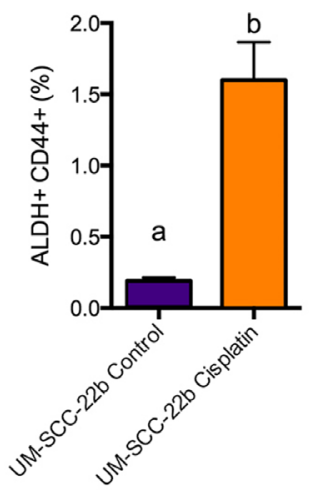

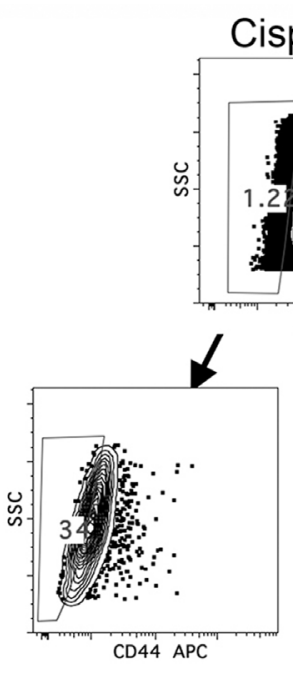

Cisplatin

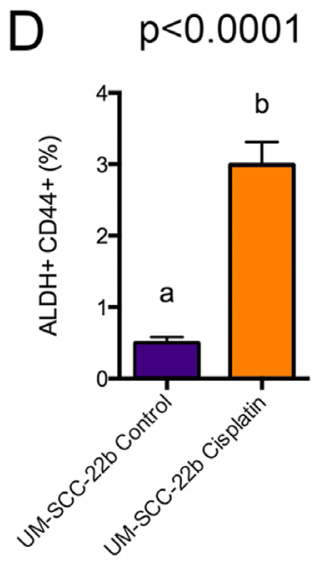

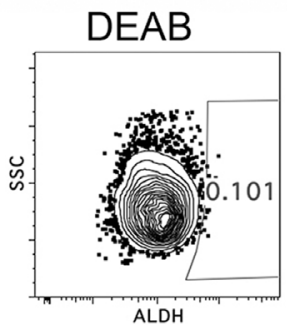

sotype

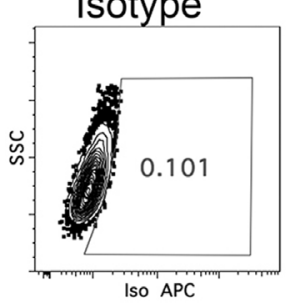

E $\quad p<0.0001$

Figure 2: FACS analysis of cisplatin treated UM-SCC-22B cells. UM-SCC-22B cells were treated for 5 days in 6-well plates with or without $2 \mu \mathrm{M}$ cisplatin. Cells were harvested, counted, stained for ALDH and CD44, and collected by FACS. (A) FACS gating schema depicting how $\mathrm{ALDH}{ }^{\text {high }} \mathrm{CD} 44^{\text {high }}$ and $\mathrm{ALDH}{ }^{\text {low }} \mathrm{CD} 44^{\text {low }}$ cell populations were collected from control (left) and $2 \mu \mathrm{M}$ cisplatin treated (right) cells. ALDH ${ }^{\text {high }}$ and CD44 ${ }^{\text {high }}$ gates were set based on DEAB control FACS samples using $0.1 \%$ as a background (right). (B-E) Average \pm standard deviation of $\mathrm{ALDH}{ }^{\text {high }} \mathrm{CD} 44^{\text {high }}$ percentage (UM-SCC-22B) for control and cisplatin groups $(N=6)$ from 4 separate FACS sorting experiments. Different letters depict statistically significant differences based on pairwise comparisons of control to cisplatin $(P<0.05)$. 
control ALDH ${ }^{\text {high }} \mathrm{CD} 44^{\text {high }}$ vs. cisplatin $\mathrm{ALDH}^{\text {high }} \mathrm{CD} 44^{\text {high }}$, including Hypoxia (Genes up-regulated in response to low oxygen levels (hypoxia)) and Notch Signaling (Genes upregulated by activation of Notch signaling) (Figure 4D-4E).

While the GSEA results suggested the role of IFN $\alpha, \mathrm{TNF} \alpha$, and/or IL6 signaling in regulating chemoresistant $\mathrm{ALDH}^{\text {high }} \mathrm{CD} 44^{\text {high }}$ cells, these secreted cytokines may be downstream effectors. We used a complimentary pathway analysis tool, iPathway, which is focused on
KEGG pathways. The iPathway software analysis tool implements an 'Impact Analysis' approach that takes into consideration the direction and type of all signals on a pathway, the position, role and type of every gene, etc. $[24,25]$. The Impact Analysis develops two $p$-values using two orthogonal approaches based on over-representation and the accumulated perturbation. These two $p$-values are combined into a global $p$-value for each pathway and iPathway adjusts for multiple testing based on Bonferroni
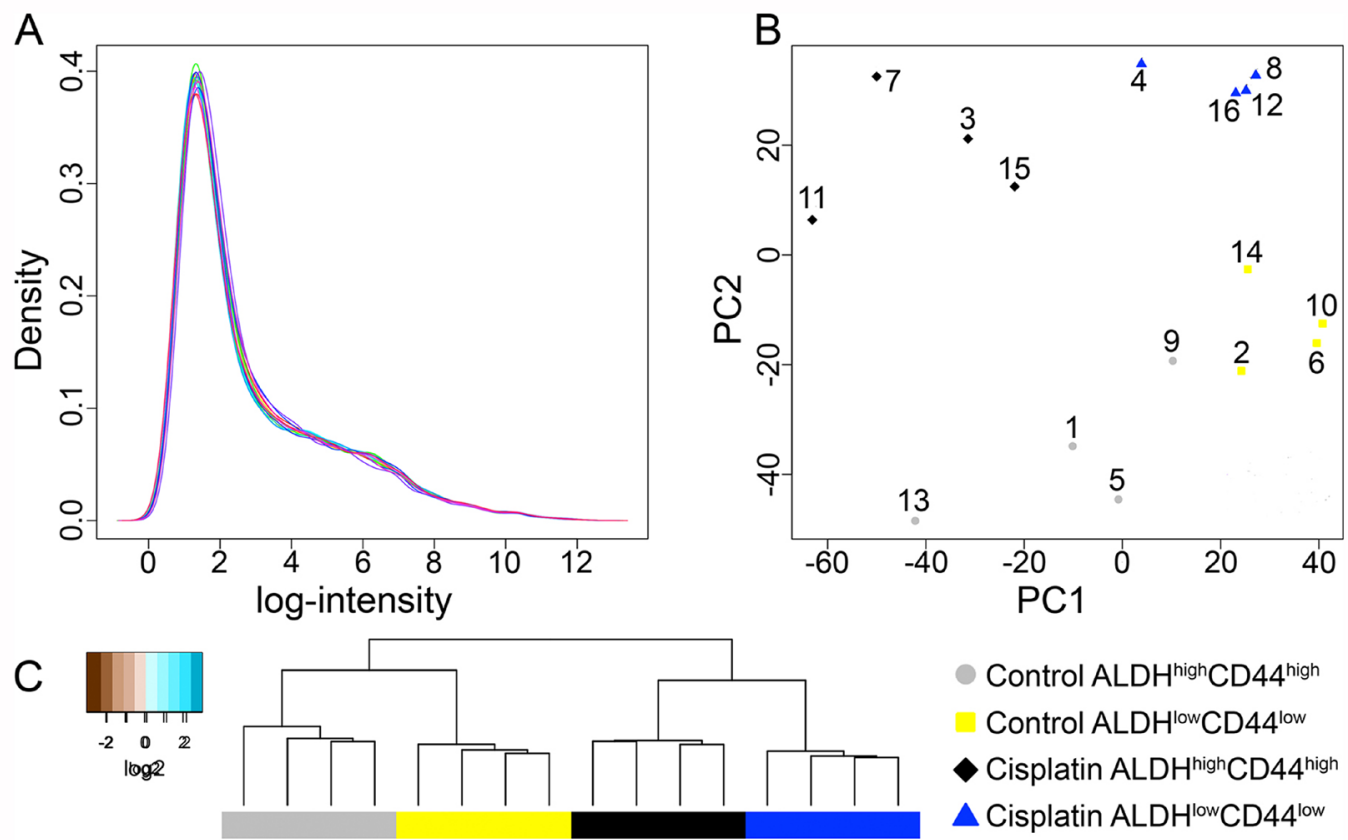

- Control ALDH ${ }^{\text {high }}$ CD44 ${ }^{\text {high }}$

Control ALDH ${ }^{\text {low }} \mathrm{CD} 44^{\text {low }}$

$\checkmark$ Cisplatin ALDH ${ }^{\text {high }}$ CD44 $4^{\text {high }}$

$\triangle$ Cisplatin ALDH ${ }^{\text {low }} \mathrm{CD} 44^{\text {low }}$

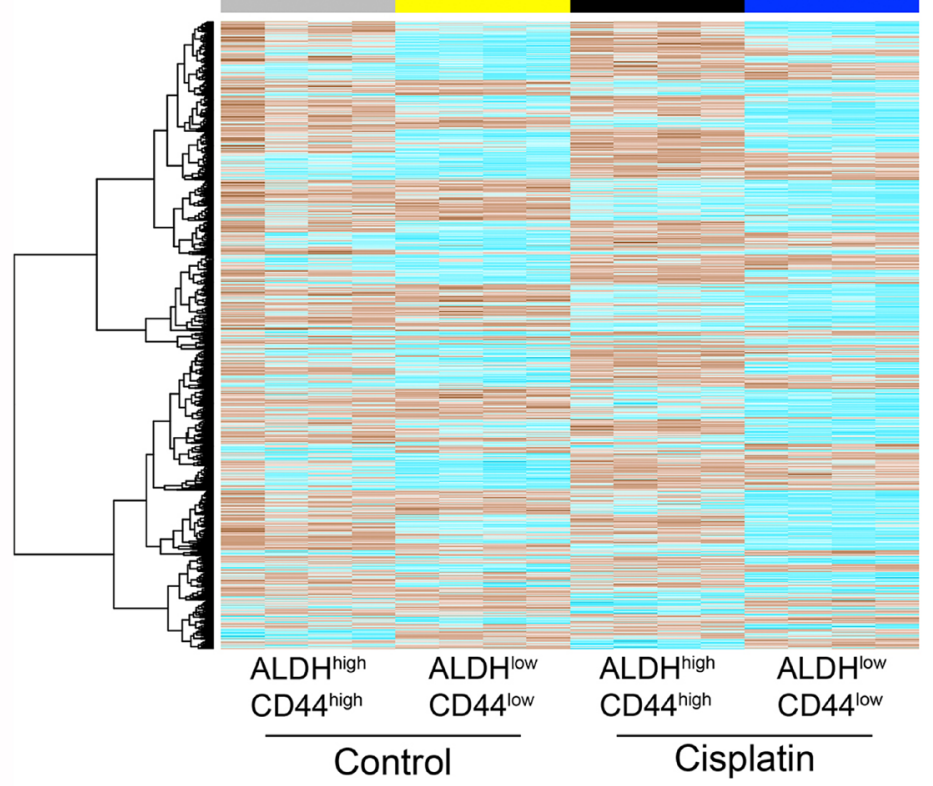

Figure 3: Microarray analysis of $\mathrm{ALDH}{ }^{\text {high }} \mathrm{CD} 44^{\text {high }}$ and $\mathrm{ALDH}{ }^{\text {low }} \mathrm{CD} 44^{\text {low }}$ cells from control and cisplatin-treated UMSCC-22B. (A) Histogram plot of $\log 2$ intensity values for 16 microarrays following batch adjustment. (B) Principal component analysis of batch adjusted 16 microarrays showing the 1 st and 2 nd components with the most variance. Grey circles-Control ALDH ${ }^{\text {high }} \mathrm{CD} 44^{\text {high }}$; yellow squares-Control ALDH ${ }^{\text {low }} \mathrm{CD} 44^{\text {low }}$; black diamonds-Cisplatin $\mathrm{ALDH}{ }^{\text {high }} \mathrm{CD} 44^{\text {high }}$; blue triangles-Cisplatin $\mathrm{ALDH}^{\text {low }} \mathrm{CD} 44^{\text {low }}$. Exp \#1: 1-4; Exp \#2: 5-8; Exp \#3: 9-12; Pilot Exp: 13-16. (C) Unsupervised hierarchical clustering with complete linkage and Euclidean distance was performed on only statistically significant probes (adjusted $p$-value $<0.05$ ). 
and FDR approaches [24, 25]. Based on comparing only statistically significant genes between cisplatin $\mathrm{ALDH}^{\text {high }} \mathrm{CD} 44^{\text {high }}$ vs. control $\mathrm{ALDH}^{\text {high }} \mathrm{CD} 44^{\text {high }}$, we identified about 20 KEGG pathways with an unadjusted $p$-value $<0.05$ (Supplementary Table 3). Adjusting for multiple testing reduced the number of significant pathways to 4-5, including Influenza A, Herpes simplex infection, Measles, Malaria, and Hepatitis C. These pathways all involve the response of the immune system. In addition, the TNF signaling and NF- $\kappa \mathrm{B}$ signaling pathways were also enriched in the iPathway analysis. For the NF- $\kappa \mathrm{B}$ signaling pathway, few genes expressed higher (e.g. DDX58, IL1 $\beta$, ICAM1) in the cisplatin $\mathrm{ALDH}^{\text {high }} \mathrm{CD} 44^{\text {high }}$ group compared to control $\mathrm{ALDH}^{\text {high }} \mathrm{CD} 44^{\text {high }}$ (Supplementary Figure 5). Similarly, there was a mix of upregulated genes (IL1 $\beta$, CCL20, ICAM1) and downregulated genes (MAPK10, MAP2K6) in the TNF signaling pathway (Supplementary Figure 6). Together, the GSEA and iPathway analyses identified similar immune system pathways in cisplatin-resistant ALDH ${ }^{\text {high }} \mathrm{CD} 44^{\text {high }}$ cells.

Even though GSEA and iPathway analyses identified similar immune signaling pathways, there remained the possibility that these pathways were more downstream effectors. Furthermore, there is substantial crosstalk between the TNF, NF- $\mathrm{BB}$, and IL6 signaling pathways hindering a more targeted approach to eradicating cisplatin $\mathrm{ALDH}^{\text {high }} \mathrm{CD} 44^{\text {high }}$ cells. Therefore, we examined the 115 genes expressed higher in cisplatin $\mathrm{ALDH}{ }^{\text {high }} \mathrm{CD} 44^{\text {high }}$ cells compared to control $\mathrm{ALDH}{ }^{\text {high }} \mathrm{CD} 44^{\text {high }}$ cells (Table 1). As expected, there were numerous immune system related genes, but there were two secreted growth factors not related to the immune system, e.g. FGF2 and EREG (Supplementary Table 4). Examination of the 116 genes expressed lower in cisplatin $\mathrm{ALDH}{ }^{\text {high }} \mathrm{CD} 44^{\text {high }}$ cells did not identify obvious regulators of cell survival, proliferation, or apoptosis (Supplementary Table 5).

EREG (epiregulin) is a member of the EGF ligand family [26]. Various members of the EGF ligand family are secreted by HNSCC cells [27]. EREG is known to promote the proliferation of dental stem cells via the MAPK and JNK signaling pathways [28]. Furthermore, EGF ligand has been shown to regulate $\mathrm{ALDH}{ }^{\text {high }} \mathrm{CD} 44^{\text {high }}$ cells in HNSCC lines [29]. FGF2 is a well-known mitogen of fibroblasts and cancer cells. More recently, FGF2 has been shown to be required for maintaining human
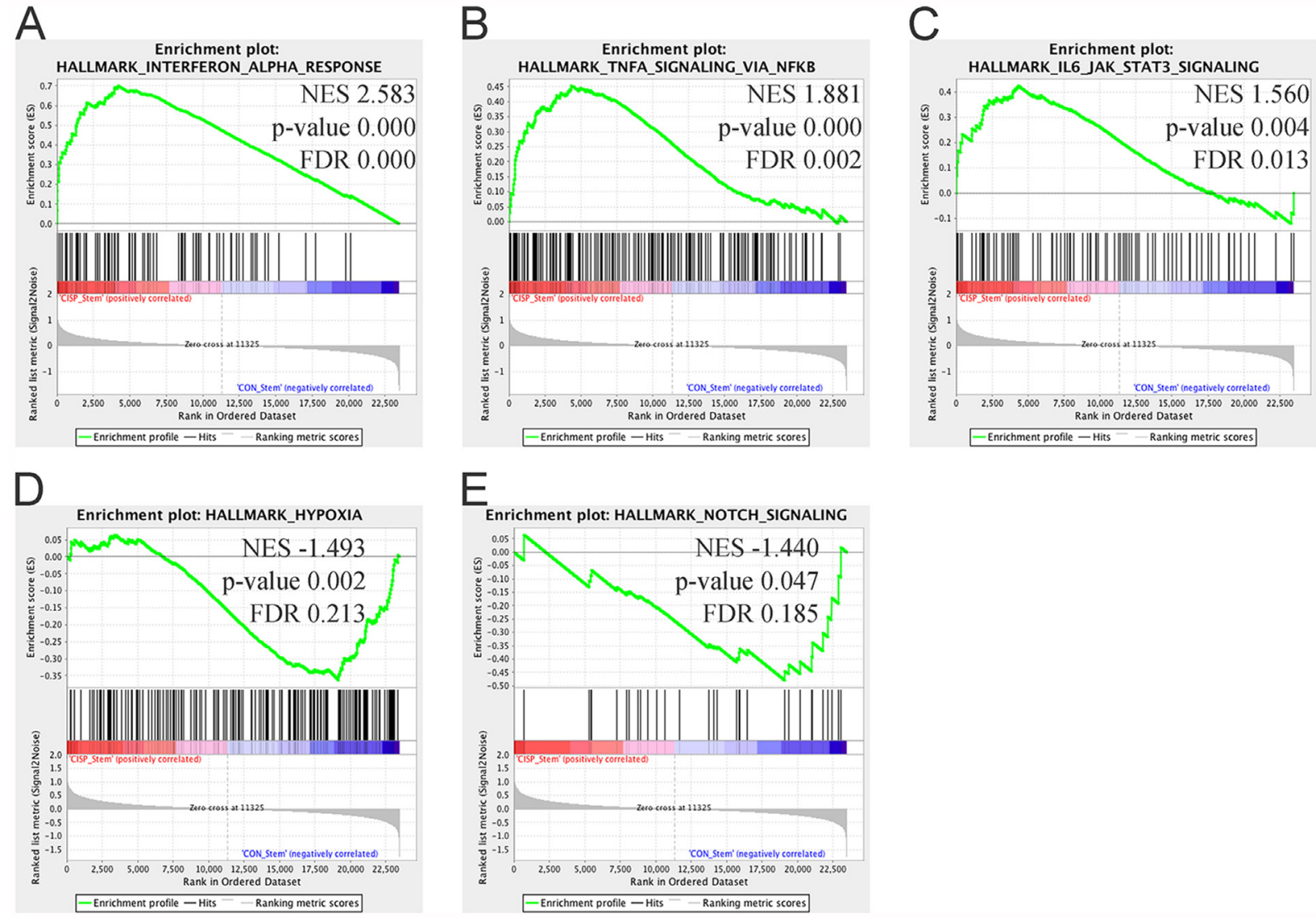

Figure 4: Gene Set Enrichment Analysis of cisplatin ALD ${ }^{\text {Hhigh }}$ CD44 ${ }^{\text {high }}$ vs. control ALDH ${ }^{\text {high }}$ CD44 $^{\text {high }}$ cells. Gene set enrichment analysis using "Hallmark" gene sets based on comparison between cisplatin ALDH ${ }^{\text {high }} \mathrm{CD} 44^{\text {high }}$ and control ALDH ${ }^{\text {high }} \mathrm{CD} 44^{\text {high }}$ cells. (A-C) Gene sets enriched in cisplatin $\mathrm{ALDH}^{\text {high }} \mathrm{CD} 44^{\text {high }}$ cells with FDR $<0.25$ and $p$-value $<0.05$. (A) Interferon Alpha Response, (B) TNF $\alpha$ Signaling Via NF-kB, (C) IL6-JAK-STAT3 Signaling. (D-E) Gene sets enriched in control ALDH ${ }^{\text {high }} \mathrm{CD} 4^{\text {high }}$ cells with FDR $<0.25$ and $p$-value $<0.05$. (D) Hypoxia, (E) Notch Signaling. NES-Normalized Enrichment Score. 
Table 1: Number of differentially expressed genes for different comparisons

\begin{tabular}{|c|c|c|c|c|}
\hline Group 1 & Group 2 & Total genes & Higher genes & Lower genes \\
\hline Cisplatin $\mathrm{ALDH}{ }^{\text {high }} \mathrm{CD} 44^{\text {high }}$ & Control ALDH ${ }^{\text {high }} \mathrm{CD} 44^{\text {high }}$ & 231 & 115 & 116 \\
\hline Control ALDH ${ }^{\text {high }} \mathrm{CD} 44^{\text {high }}$ & Control ALDH ${ }^{\text {low }} \mathrm{CD} 44^{\text {low }}$ & 363 & 81 & 282 \\
\hline Cisplatin $\mathrm{ALDH}{ }^{\text {high }} \mathrm{CD} 44^{\text {high }}$ & Cisplatin $\mathrm{ALDH}^{\text {low }} \mathrm{CD} 44^{\text {low }}$ & 605 & 104 & 501 \\
\hline Cisplatin $\mathrm{ALDH}^{\text {low }} \mathrm{CD} 44^{\text {low }}$ & Control ALDH ${ }^{\text {low }} \mathrm{CD} 44^{\text {low }}$ & 1036 & 582 & 454 \\
\hline
\end{tabular}

For each comparison, the total number of genes with an FDR adjusted $p$-value $<0.05$, the number of genes higher in group 1, and the number of genes lower in group 1. Only genes with HUGO gene symbol are consider in this analysis.

embryonic stem cells via promotion of self-renewal [30]. Marshall et al. showed FGFR signaling was dominant or co-dominant with EGFR in six HNSCC lines, whereas three lines exhibited little or no role for FGFRs and were highly EGFR dependent [31]. Therefore, HNSCC cell lines can be divided into subsets defined by sensitivity to EGFR and FGFR-specific inhibitors, which suggest FGFR inhibitors may represent novel therapeutics alone or in combination with EGFR inhibitors. Together, these data suggested FGF2 and/or EREG might regulate the resistance of $\mathrm{ALDH}{ }^{\text {high }} \mathrm{CD} 44^{\text {high }}$ cells to cisplatin.

We hypothesized that increased FGF2 and/or EREG secretion by cisplatin $\mathrm{ALDH}^{\text {high }} \mathrm{CD} 44^{\text {high }}$ cells may contribute to the survival of these cells. Since FGF2 and EREG mRNA were increased in both cisplatin $\mathrm{ALDH}^{\text {high }} \mathrm{CD} 44^{\text {high }}$ vs. control $\mathrm{ALDH}^{\text {high }} \mathrm{CD} 44^{\text {high }}$ and cisplatin $\mathrm{ALDH}^{\text {low }} \mathrm{CD} 44^{\text {low }}$ vs. control $\mathrm{ALDH}^{\text {low }} \mathrm{CD} 44^{\text {low }}$ (Supplementary Figure 7), we anticipated that FGF2 and/ or EREG would be secreted by both $\mathrm{ALDH}^{\text {high }} \mathrm{CD} 44^{\text {high }}$ and $\mathrm{ALDH}^{\text {low }} \mathrm{CD} 44^{\text {low }}$ cells following cisplatin treatment. We treated UM-SCC-1 and UM-SCC-22B cells for 5 days with $2 \mu \mathrm{M}$ cisplatin and used ELISA to assay FGF2 and EREG protein in the media supernatant. As shown in Figure 5A, FGF2 secretion was dramatically increased in UM-SCC-1 and UM-SCC-22B cells following 5-day cisplatin treatment. Of note, FGF2 was expressed at low levels in untreated UM-SCC-1 cells, but not expressed in untreated UM-SCC22B. However, EREG secretion was inconsistent between the triplicate wells and very low (Figure 5B).

The GSEA and iPathway analyses suggested a role for major signaling pathways in cisplatin-resistant $\mathrm{ALDH}^{\text {high }} \mathrm{CD} 44^{\text {high }}$ cells (e.g. TNF $\left.\alpha, \mathrm{IFN}, \mathrm{IL6}, \mathrm{NF}-\kappa \mathrm{B}\right)$ that are known to regulate cell proliferation, survival, and participate in major biological processes (e.g. immune responses). However, IL1 $\beta$ (interleukin 1 $\beta$ ) mRNA was the only cytokine statistically higher in cisplatin $\mathrm{ALDH}^{\text {high }} \mathrm{CD} 44^{\text {high }}$ vs. control $\mathrm{ALDH}{ }^{\text {low }} \mathrm{CD} 44^{\text {low }}$. It was recently shown that exogenous IL6 treatment cooperates with cisplatin to further increase $\mathrm{ALDH}{ }^{\text {high }} \mathrm{CD} 44^{\text {high }}$ cells in HNSCC lines [21]. Therefore, we tested by ELISA if UMSCC-1 and UM-SCC-22B secreted various cytokines in response to 5-day cisplatin treatment. In agreement with an increase with IL1 $\beta$ mRNA in cisplatin $A L D H^{\text {high }}$ CD $44^{\text {high }}$ cells, there was an increase in IL1 $\beta$ secretion in UM-SCC22B cells (Figure 5D). However, the levels of secretion were generally low and not statistically different in UMSCC-1. IL1 $\alpha$, IL6, and IL8 secretion was highly induced in both UM-SCC-1 and UM-SCC-22B (Figure 5C, 5E, 5F). Interestingly, CCL5/Rantes secretion was reduced in UM-SCC-1 but increased in UM-SCC-22B (Figure 5G). Together, these data suggest that several major signaling pathways may regulate the pathobiology of cisplatinresistant $\mathrm{ALDH}{ }^{\text {high }} \mathrm{CD} 44^{\text {high }}$ cells.

The dramatic increase in FGF2 secretion in both UM-SCC-1 and UM-SCC-22B cells following cisplatin treatment suggested cisplatin-resistant $\mathrm{ALDH}{ }^{\text {high }} \mathrm{CD} 44^{\text {high }}$ cells might utilize FGF signaling for survival. To inhibit the FGF2 signaling, we focused on testing an FGFR inhibitor. Recently, FGFR small-molecule kinase inhibitors with increased specificity compared to similar kinases (e.g. ABL, FYN, KIT, LCK, LYN, YES) have been reported. One such inhibitor, BGJ398, targets FGFR1, FGFR2, FGFR3, and FGFR4, and at nanomolar concentrations inhibits cell proliferation of $\mathrm{BaF} 3$ cells over expressing those receptors [32]. This inhibitor is currently in Phase II clinical trials for solid cancers, especially in patients with FGFR genetic alterations [33]. At nanomolar levels BGJ398 kills bladder cancer cells overexpressing wildtype FGFR3 (e.g. RT112, RT4, SW780, and JMSU1), but requires more than $3 \mu \mathrm{M}$ to kill cells lacking this receptor [32]. Guagnano and collaborators tested $18 \mathrm{HNSCC}$ cell lines and found that more than $8 \mu \mathrm{M}$ BGJ398 was needed to kill these cells [33].

Here, we determined the BGJ398 $\mathrm{IC}_{50}$ for UM-SCC-1 and UM-SCC-22B cells. Both cell lines were seeded in 96well plates for 3 or 5 days and treated at increasing doses of BGJ398. After 3 days of treatment, both UM-SCC-1 and UM-SCC-22B were killed with a BGJ398 IC $_{50}$ concentration around $2.2 \mu \mathrm{M}$ (Supplementary Figure 8A, Supplementary Table 6). However, after 5 day BGJ398 treatment, UM-SCC22B required a higher $\mathrm{IC}_{50}$ concentration at $3.57 \pm 0.26 \mu \mathrm{M}$ (Supplementary Figure 8B, Supplementary Table 6). After 5 days, UM-SCC-1 cells were killed with an $\mathrm{IC}_{50}$ similar to 3-day treatment $(1.91 \pm 0.31 \mu \mathrm{M})$.

To verify the effect of BGJ398 in HNSCC cell lines, we treated UM-SCC-1 and UM-SCC-22B cells with increasing concentrations of BGJ398 for 24 hours. Western blots revealed a dose-dependent decrease in FGFR2 protein levels, thus confirming the ability of BGJ398 to inhibit the FGF signaling 
pathway (Figure 6A). To begin to understand the effect of therapeutic inhibition of FGFR2 in HNSCC, we performed propidium iodide (PI) staining of cells treated with increasing doses of BGJ398 (Figure 6B-6D). We observed that BGJ398 mediated a dose-dependent increase in apoptotic cells (sub- $\mathrm{G}_{0} / \mathrm{G}_{1}$ fraction) in UMSCC-22B cells. On the other hand, BGJ398 caused a decrease in the fraction of cells in the $\mathrm{S}$ phase of cell cycle (without significant effect on apoptosis) in UMSCC-1 cells, indicating that the effect of BGJ398 in this cell line was primarily to slow down in cell proliferation. While the mode of action of BGJ398 in these 2 cell lines was different, the net result in both is a decrease in the overall number of cells (Figure 7A, 7E).

To investigate if BGJ398 was able to target cisplatinresistant $\mathrm{ALDH}{ }^{\text {high }} \mathrm{CD} 44^{\text {high }}$ cells, we tested $\mathrm{BGJ} 398$ treatment at various doses $(1-5 \mu \mathrm{M})$ with or without 2 $\mu \mathrm{M}$ cisplatin. BGJ398 doses were chosen to flank the $\mathrm{IC}_{50}$ concentration at doses that had minimal toxicity or overt toxicity. UM-SCC-1 and UM-SCC-22B cells were treated in 6-well plates and treatments replaced every two days for a total of $\sim 120 \mathrm{hr}$ treatment. We examined the absolute number of cells, the frequency of ALDH ${ }^{\text {high }} \mathrm{CD} 44^{\text {high }}$, and absolute number of $\mathrm{ALDH}^{\text {high }} \mathrm{CD} 44^{\text {high }}$ cells. In agreement with the Alamar Blue data (Supplementary Figure 8, Supplementary Table 6), UM-SCC-1 cells were killed with a BGJ398 $\mathrm{IC}_{50}$ around $2.35 \mu \mathrm{M}$ both in the presence or absence of $2 \mu \mathrm{M}$ cisplatin (Figure 7A, 7B). The addition of $2 \mu \mathrm{M}$ cisplatin dramatically reduced the number of UMSCC-1 cells in combination with 3 , 4, or $5 \mu \mathrm{M}$ BGJ398. The massive cell loss at these doses prevented flow cytometry examination of $\mathrm{ALDH}{ }^{\text {high }} \mathrm{CD} 44^{\text {high }}$ frequency. Examination of $\mathrm{ALDH}^{\text {high }} \mathrm{CD} 44^{\text {high }}$ frequency showed a statistical reduction at 2,3, and $4 \mu \mathrm{M}$ BGJ398 compared to the control group (Figure 7C). Unexpectedly, there was not an enrichment of $\mathrm{ALDH}^{\text {high }} \mathrm{CD} 44^{\text {high }}$ cells at $2 \mu \mathrm{M}$ cisplatin in this experiment. Furthermore, there was no statistically significant reduction of $\mathrm{ALDH}^{\text {high }} \mathrm{CD} 44^{\text {high }}$ frequency for cisplatin $+1 \mu \mathrm{M}$ BGJ398 or cisplatin $+2 \mu \mathrm{M}$ BGJ398 when compared to cisplatin (Figure 7C). Given the sizable reduction in overall cell numbers (Figure 7A) and reduction in $\mathrm{ALDH}^{\text {high }} \mathrm{CD} 44^{\text {high }}$ frequency (Figure $7 \mathrm{C}$ ), it was expected that the overall number of $\mathrm{ALDH} \mathrm{H}^{\text {high }} \mathrm{CD} 44^{\text {high }}$ cells decreased for most groups (Figure 7D).
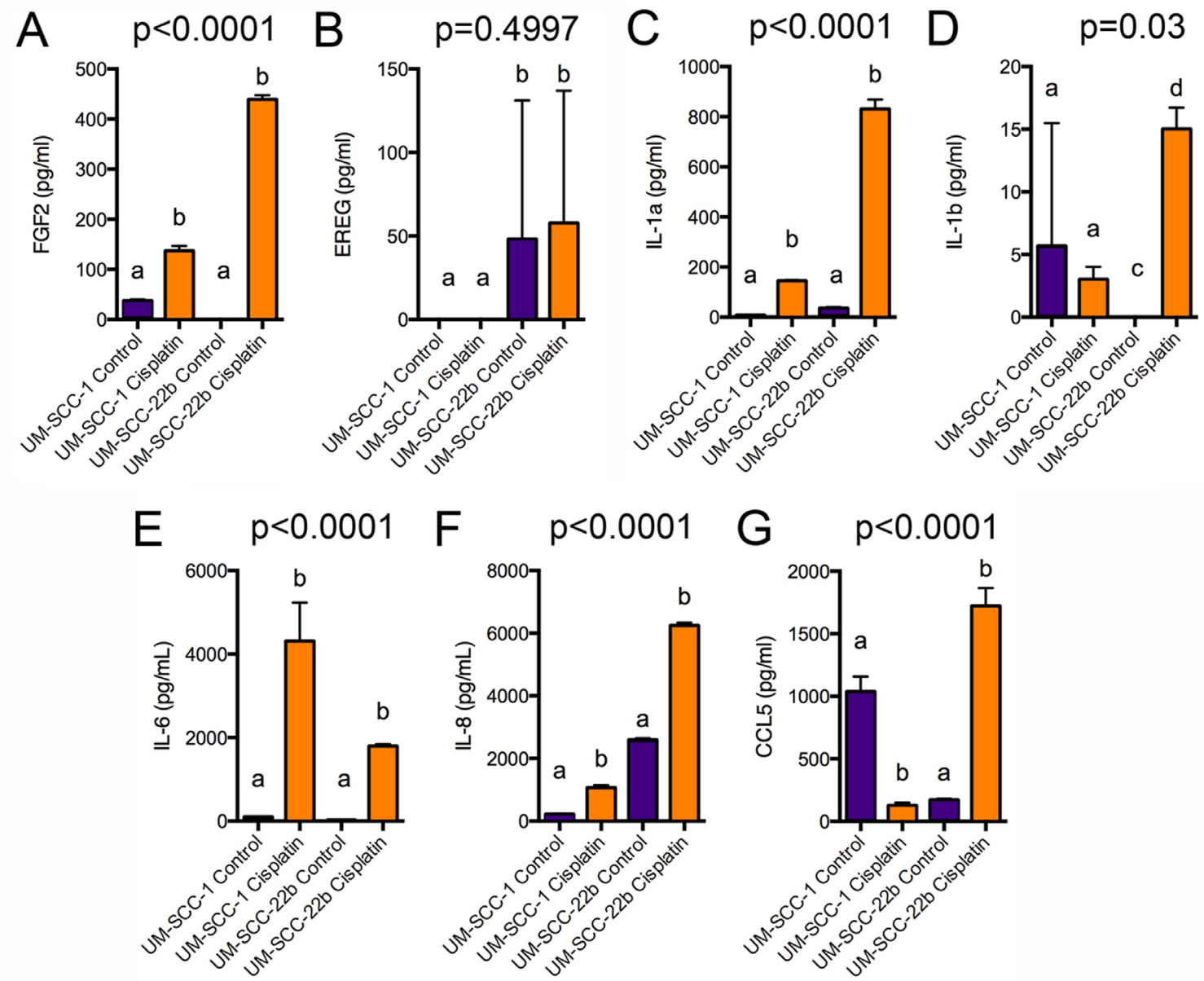

Figure 5: ELISA analysis of FGF2, EREG, and cytokine secretion. UM-SCC-1 and UM-SCC-22B cells were treated for 5 days with $2 \mu \mathrm{M}$ cisplatin, which was replaced every 2 days. Cell supernatant was centrifuged and analyzed by ELISA for (A) FGF2, (B) EREG, (C) IL-1 $\alpha$, (D) IL-1 $\beta$, (E) IL-6, (F) IL-8, or (G) CCL5 secretion. Different letters depict statistically significant differences based on pairwise comparisons of control to cisplatin $(P<0.05)$. 
We performed identical experiments with UMSCC-22B cells to determine if BGJ398 could target cisplatin-resistant $\mathrm{ALDH}{ }^{\text {high }} \mathrm{CD} 44^{\text {high }}$ cells. In the absence of cisplatin, BGJ398 killed UM-SCC-22B cells with an $\mathrm{IC}_{50}$ of $2.91 \pm 0.16 \mu \mathrm{M}$ (Figure $7 \mathrm{E}, 7 \mathrm{~F}$ ). This result was similar to the Alamar Blue data (Supplementary Figure 8, Supplementary Table 6 ). In the presence of $2 \mu \mathrm{M}$ cisplatin, the BGJ398 $\mathrm{IC}_{50}$ decreased to $1.49 \pm 0.12 \mu \mathrm{M}$ suggesting some cell-killing synergy between cisplatin and BGJ398. Due to the lack of cells at $5 \mu \mathrm{M}$ BGJ398, cisplatin $+4 \mu \mathrm{M}$ BGJ398, and cisplatin $+5 \mu \mathrm{M}$ BGJ398 (Figure 7E), we were not able to examine $\mathrm{ALDH}^{\text {high }} \mathrm{CD} 44^{\text {high }}$ cells. Additionally, there were only enough cells in the cisplatin $+3 \mu \mathrm{M}$ BGJ398 group to examine $\mathrm{ALDH}{ }^{\text {high }} \mathrm{CD} 44^{\text {high }}$ without replicates, which prevented statistical testing. In contrast to the reduction of $\mathrm{ALDH}{ }^{\text {high }} \mathrm{CD} 44^{\text {high }} \mathrm{UM}$ SCC-1 cells by BGJ398 treatment (Figure 7C), BGJ398 as a single agent did not reduce $\mathrm{ALDH}^{\text {high }} \mathrm{CD} 44^{\text {high }} \mathrm{UM}-$ SCC-22B cells (Figure 7G). As expected, $2 \mu \mathrm{M}$ cisplatin dramatically increased the $\mathrm{ALDH}{ }^{\text {high }} \mathrm{CD} 44^{\text {high }}$ percentage and overall cell number control compared to the control group (Figure $7 \mathrm{G}, 7 \mathrm{H}$ ). When treated with $2 \mu \mathrm{M}$ cisplatin there was substantial reduction in the percentage and absolute number of $\mathrm{ALDH}{ }^{\text {high }} \mathrm{CD} 44^{\text {high }}$ cells with increasing BGJ398 concentration. While there was a $25 \%$ reduction in overall cell number from cisplatin compared to cisplatin $+1 \mu \mathrm{M}$ BGJ398, there was a $50 \%$ reduction in absolute $\mathrm{ALDH}^{\text {high }} \mathrm{CD} 44^{\text {high }}$ cells suggesting the combination preferentially targets $\mathrm{ALDH}{ }^{\text {high }} \mathrm{CD} 44^{\text {high }}$ cells.

We used the orosphere assay (i.e. survival/growth of head and neck tumor spheres in serum-free, ultra-low attachment conditions) to verify the impact of FGFR signaling on the phenotype of $\mathrm{ALDH}{ }^{\text {high }} \mathrm{CD} 44^{\text {high }}$ cells. Cells were plated at single-cell densities and were treated
A

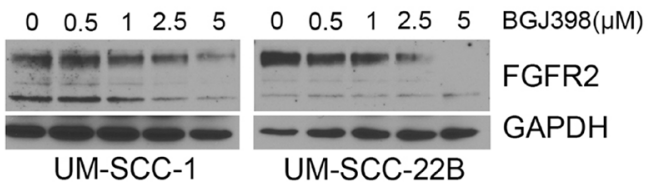

B

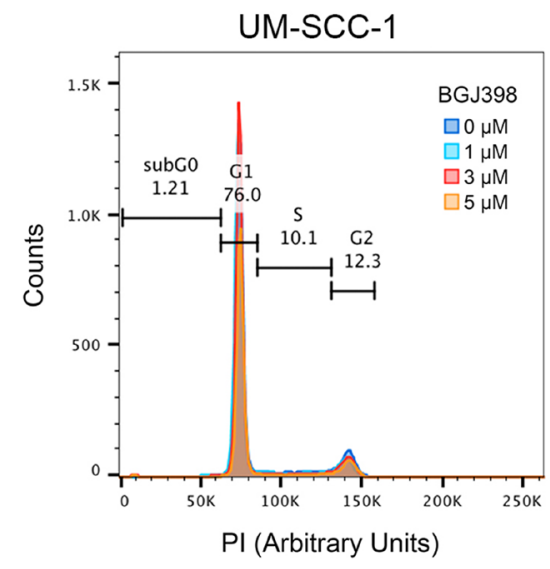

D

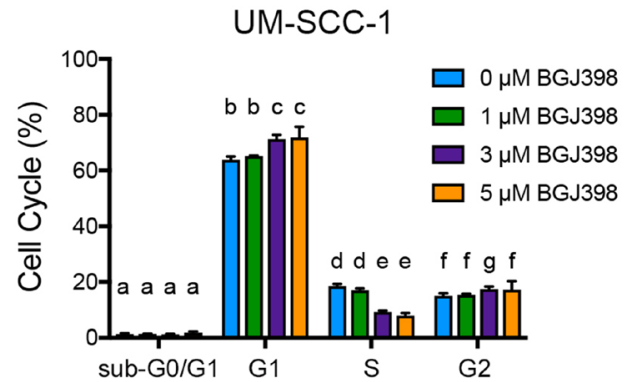

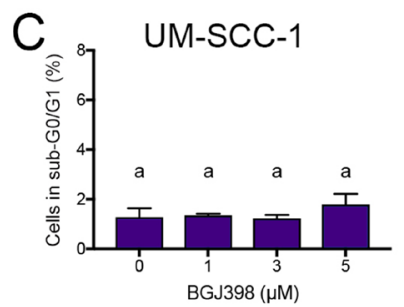
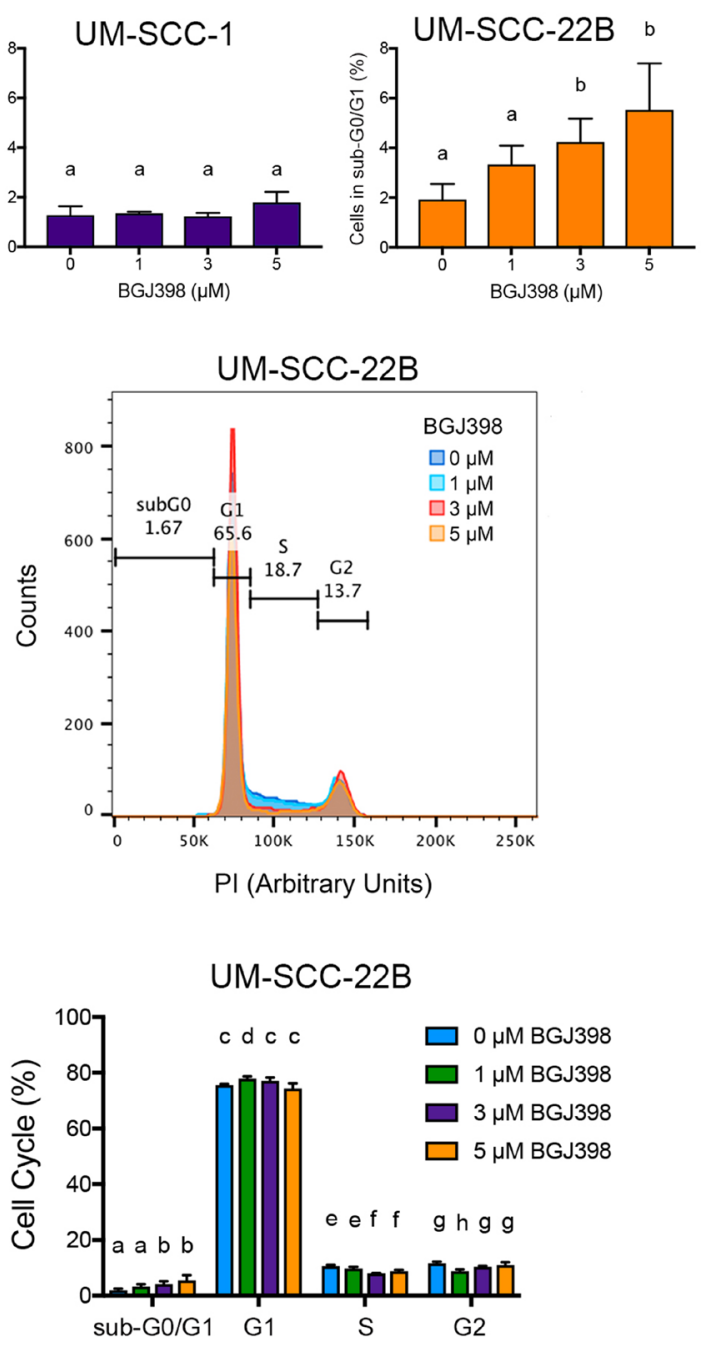

Figure 6: Effect of FGFR2 inhibition with BGJ398 on head and neck cancer cells. (A) Western blot of UM-SCC-1 and UM-SCC-22B cells treated for 24 hours with increasing doses of BGJ398 $(0.5-5 \mu \mathrm{M})$. (B-D) Cell cycle analysis with propidium iodide of UM-SCC-1 and UM-SCC-22B cells treated with increasing doses of BGJ398 (1-5 $\mu \mathrm{M})$ for 24 hours. (B) Overlay of propidium iodide spectra for all conditions. (C) Overview of cells in sub- $\mathrm{G}_{0} / \mathrm{G}_{1}$. (D) Quantification of cells in each cell cycle stage. Different letters depict statistically significant differences based on multiple comparisons analysis. $(P<0.05)$. 

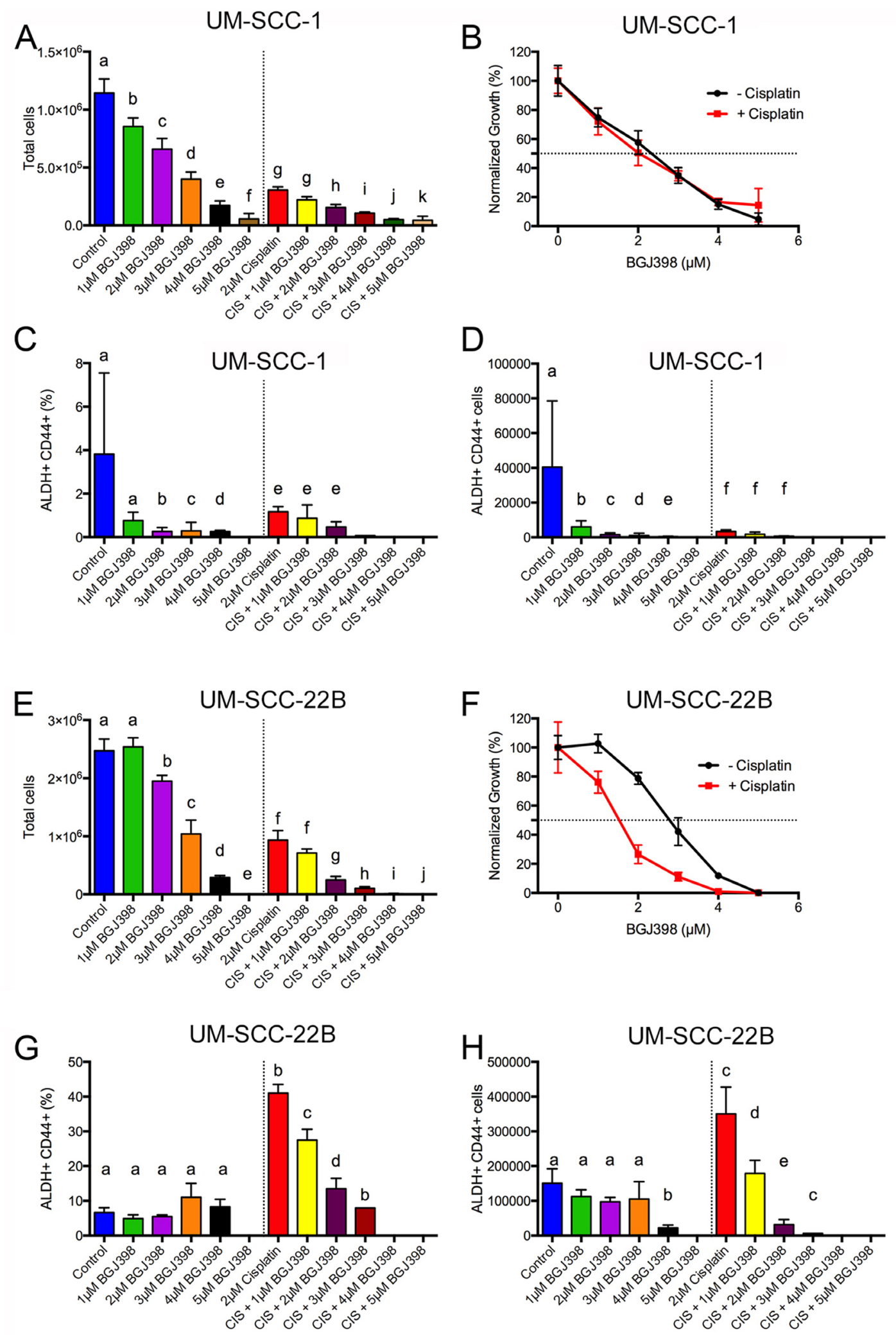

Figure 7: BGJ398 targeting of cisplatin-resistant ALDH ${ }^{\text {high }}$ CD44 ${ }^{\text {high }}$ cells. 50,000 (A-D) UM-SCC-1 or (E-H) UM-SCC-22B cells were treated for 5 days with or without $2 \mu \mathrm{M}$ cisplatin at various doses of BGJ398 (1-5 $\mu \mathrm{M})$. Cells were harvested, counted, and stained with Aldefluor assay and CD44. (A, E) Number of total cells. (B, F) Normalized growth for total cells in the absence (black circles) or presence of $2 \mu \mathrm{M}$ cisplatin (red squares). $(\mathrm{C}, \mathrm{G})$ Percentage of $\mathrm{ALDH}^{\text {high }} \mathrm{CD} 44^{\text {high }}$ cells. $(\mathrm{D}, \mathrm{H})$ Number of $\mathrm{ALDH}^{\text {high }} \mathrm{CD} 44^{\text {high }}$ cells. Average \pm standard deviation. Different letters depict statistically significant differences based on pairwise comparisons to control (blue) or to cisplatin (red) $(P<0.05)$. 
with increasing doses of BGJ398 for 4 days. Treatment with BGJ398 resulted in a dose-dependent decrease in the number of orospheres (Figure 8), confirming a role for FGFR signaling in in vitro stemness properties of head and neck cancer cells.

To verify the results obtained with BGJ398, we silenced FGFR2 in UM-SCC-22B cells using stably transduced shRNA constructs encoded in lentiviral vectors. We first confirmed silencing of FGFR2 via western blot analysis (Figure 9A). We then examined the impact of FGFR2 in the fraction of $\mathrm{ALDH}^{\text {high }} \mathrm{CD} 44^{\text {high }}$ cells upon treatment with cisplatin. As expected, cisplatin treatment of the shRNA-control cells (scrambled sequence) mediated an increase in the fraction of cancer stem cells $\left(\mathrm{ALDH}{ }^{\text {high }} \mathrm{CD} 44^{\text {high }}\right)$. In contrast, cisplatin no longer increased the fraction $\mathrm{ALDH}^{\text {high }} \mathrm{CD} 44^{\text {high }}$ cells in FGFR2-silenced cells (Figure 9B), mimicking results obtained with the FGFR inhibitor BGJ398 (Figure 7G).

\section{DISCUSSION}

The relative resistance of $\mathrm{ALDH} \mathrm{H}^{\text {high }} \mathrm{CD} 44^{\text {high }} \mathrm{HNCSCs}$ to chemotherapy represents a therapeutic challenge. These cells are predicted to mediate recurrence and metastatic spread, which ultimately leads to organ failure and eventual death from HNSCC. Current treatments for HNSCC include chemotherapy and radiation therapy for the vast majority of patients. Except for cetuximab, the EGFR monoclonal antibody, there are no molecularly targeted therapeutics for HNSCC. The addition of cetuximab to chemotherapy prolonged the median progression-free survival time from 3.3 to 5.6 months and overall survival from 7.4 to 10.1 months [10]. Therapeutic targeting of chemo-resistant HNCSCs requires a greater understanding of the molecular pathways within these cells.

We met this need with microarray analysis of cisplatin-resistant $\mathrm{ALDH} \mathrm{H}^{\text {high }} \mathrm{CD} 44^{\text {high }}$ cells and therapeutic

\section{A}

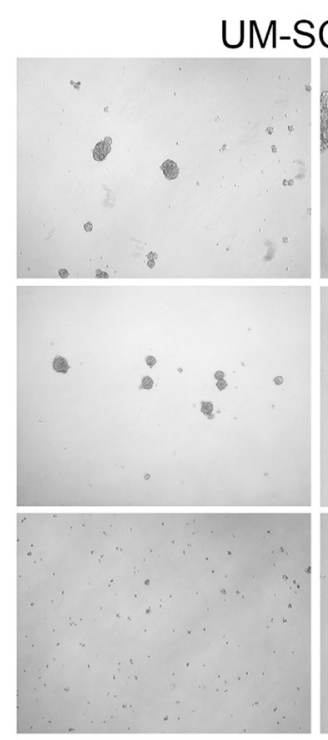

$40 x$

B

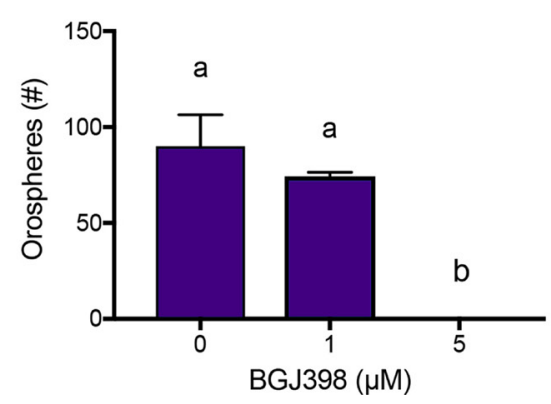

UM-SCC-22B

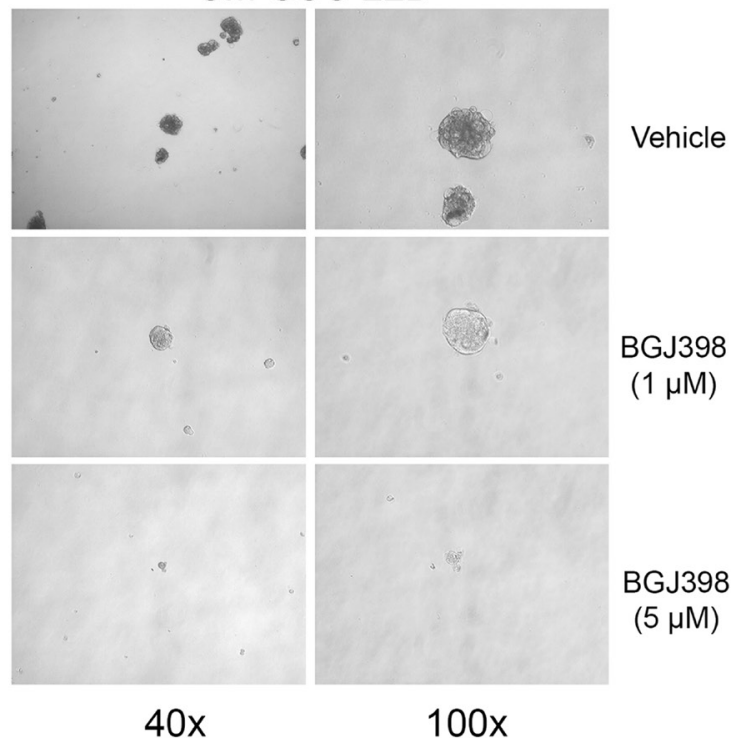

UM-SCC-22B

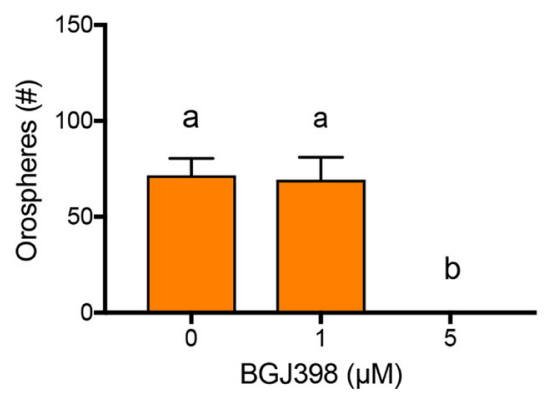

Figure 8: BGJ398 inhibits sphere formation of the UM-SCC-1 and UM-SCC-22B cells. 12,000 UM-SCC-1 and UM-SCC-22B cells grown in ultralow attachment and serum-free conditions were treated with increasing doses of BGJ398. Spheres were counted 4 days post-treatment. (A) Representative micrographs of each condition taken at $40 \times$ and $100 \times$ magnification. (B) Quantification of formed spheres. Averages \pm standard deviations. $(P<0.05)$. 
targeting of those cells by inhibition of the FGF pathway. Cisplatin represents standard chemotherapeutic treatment for HNSCC and we utilized published cisplatin $\mathrm{IC}_{50}$ concentrations $(2 \mu \mathrm{M})$ for two HNSCC cell lines. At $2 \mu \mathrm{M}$ cisplatin, there was a significant and consistent increase in $\mathrm{ALDH}^{\text {high }} \mathrm{CD} 44^{\text {high }}$ cells around 5 days of treatment (Figure 1). A pilot microarray of control and cisplatin-treated $\mathrm{ALDH}{ }^{\text {high }} \mathrm{CD} 44^{\text {high }}$ and $\mathrm{ALDH}{ }^{\text {low }} \mathrm{CD} 44^{\text {low }}$ cells identified a few upregulated genes in cisplatinresistant $\mathrm{ALDH}^{\text {high }} \mathrm{CD} 44^{\text {high }}$ cells compared to control $\mathrm{ALDH}^{\text {high }} \mathrm{CD}^{4} 4^{\text {high }}$ cells, including FGF2, EREG, AREG, and SPRR1B. SPRR1B was previously reported to be expressed in HNSCC ALDH ${ }^{\text {high }}$ cells [36]. The EGF family is known to regulate HNSCC growth, EGFR kinase inhibitors are currently in clinical development for HNSCC treatment, and cetuximab is approved for the treatment of HNSCC $[6,10,29]$. There were 235 probesets higher or lower in cisplatin-resistant $\mathrm{ALDH}{ }^{\text {high }} \mathrm{CD} 44^{\text {high }}$ cells, suggesting that additional microarray experiments would provide a robust set of genes for downstream pathway and investigational analysis.

Based on these initial microarray results, we performed additional microarrays of control and cisplatin $\mathrm{ALDH}^{\text {high }} \mathrm{CD} 44^{\text {high }}$ and $\mathrm{ALDH}{ }^{\text {low }} \mathrm{CD} 44^{\text {low }}$ cells. To increase statistical power, we combined the microarray data from the pilot and subsequent experiments. However, there were obvious batch effects, particularly for the samples analyzed in our pilot studies (Supplementary Figure 4), which affected the discovery of differentially expressed genes. Following adjustment of batches and experiments using ComBat [22], we performed pairwise comparisons to identify differentially expressed genes. Bioinformatic analysis using two complementary approaches, GSEA [25] and iPathway [24, 25], were used to identify potential pathways regulating cisplatin-resistant $\mathrm{ALDH}{ }^{\text {high }} \mathrm{CD} 44^{\text {high }}$ cells. Both pathway analyses identified an enrichment of immune signaling pathways, including TNF $\alpha$, IFN, IL6JAK-STAT3, and NF-кB.
There is growing literature showing a role for "traditional" immune signaling pathways in regulating cancer and CSCs. IL6/STAT signaling is known to increase breast CSCs [35, 36] and HNCSCs [18, 21]. Tocilizumab, an IL6 receptor monoclonal antibody, is FDA-approved for rheumatoid arthritis and pre-clinical studies have shown tocilizumab targets CSCs [18, 36]. In addition, STAT inhibitors are known to target CSCs [37]. In contrast to IL6/STAT signaling, very little data exists showing a direct role of TNF signaling on CSCs. Recently, Zhang et al. showed that exogenous TNF increased expression of Oct4, Nanog, and BMI1, genes related to "stemness", in renal cell carcinoma cells [37]. TNF also increased tumorsphere formation by renal cell carcinoma cells and induced an epithelial-mesenchymal transition. Both tumorsphere formation and epithelial-mesenchymal transition are associated with stemness [38-40]. The NF$\kappa \mathrm{B}$ pathway is also known to regulate CSCs, especially in breast cancer, and NF- $\kappa \mathrm{B}$ inhibitors target CSCs [41-43].

In agreement with the pathway analysis of the microarray data, we detected significant secretion of IL1 $\alpha$, IL6, and IL8 in both UM-SCC-1 and UM-SCC$22 \mathrm{~B}$ cells treated with cisplatin (Figure 5). IL1 $\beta$ secretion was induced by cisplatin in only UM-SCC-22B cells. Interestingly, CCL5 secretion was decreased by cisplatin in UM-SCC-1 but increased in UM-SCC-22B cells. CCL5 was found, in combination with FGF2, phospholipase $\mathrm{C}$ (PLCg2), frizzled receptor-4 (FZD4), and chemokine [C-X3-C motif] (CX3CL1), to be overexpressed in bevacizumab-resistant HNSCC [44]. Antiangiogenic agents, such as bevacizumab, increase breast CSCs via tumor hypoxia [45], which might also be via up regulation of CCL5. It has been reported that HNSCC has been shown to express a number of chemokines, and their receptors, which may promote chemotherapy resistance [46]. At the mRNA level, most HNSCC lines express CCL5, CCL20, CXCL1, CXCl2, CXCL3, CXCL10, and CXCL11 [47]. Here, we found CCL20 was expressed
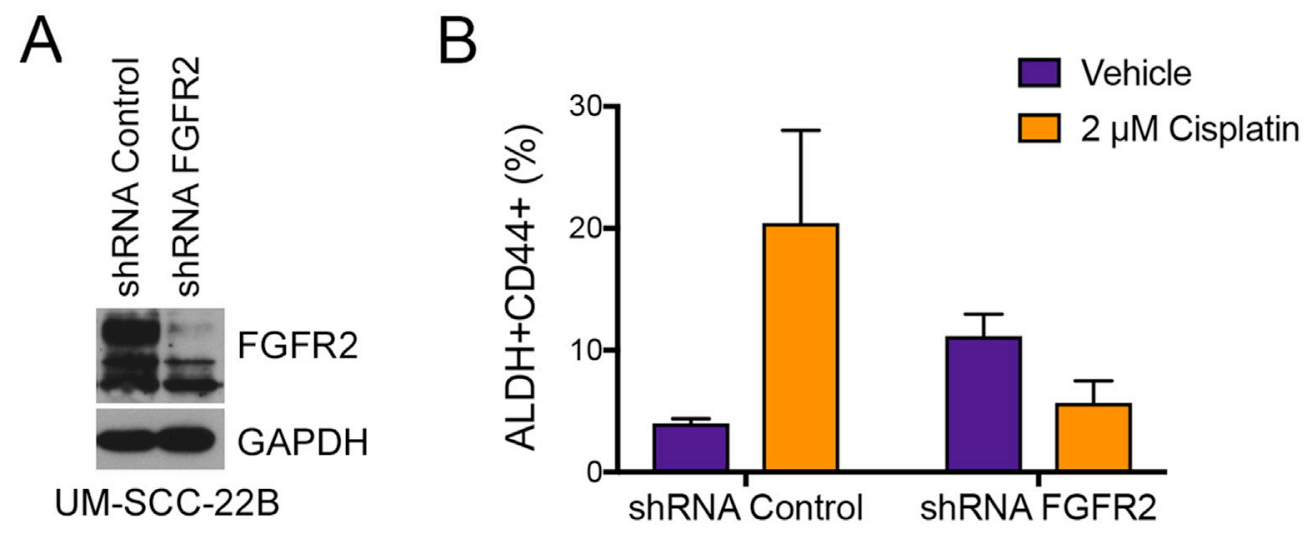

Figure 9: FGFR2 mediates cisplatin-induced increase in the fraction head and neck cancer stem cells. Stable knockdown of FGFR2 was achieved using lentiviral shRNA constructs. (A) Western blot demonstrating successful shRNA-mediated knockdown of FGFR2 in UM-SCC-22B cells. (B) Analysis of the fraction of cancer stem cells (i.e. ALDH ${ }^{\text {high }}$ CD $44^{\text {high }}$ ) cells after 4 days of treatment with $2 \mu \mathrm{M}$ Cisplatin. Averages \pm standard deviations. 
2-fold higher in cisplatin-resistant $\mathrm{ALDH} \mathrm{H}^{\text {high }} \mathrm{CD} 44^{\text {high }}$ cells compared to control $\mathrm{ALDH}^{\text {high }} \mathrm{CD} 44^{\text {high }}$ cells suggesting future studies of CCL20 may provide insight into chemotherapy resistance.

The microarray data suggest a substantial induction of immune signaling pathways by cisplatin-resistant cells. It is possible that increased cytokine and chemokine secretion by cisplatin-resistant $\mathrm{ALDH}{ }^{\text {high }} \mathrm{CD} 44^{\text {high }}$ and $\mathrm{ALDH}^{\text {low }} \mathrm{CD} 44^{\text {low }}$ cells would attract immune cells within the context of a tumor. These immune cells would secrete additional cytokines and chemokines that could provide survival signals to $\mathrm{ALDH}^{\text {high }} \mathrm{CD} 44^{\text {high }}$ cells. This bystander effect was demonstrated in breast CSCs resistant to chemotherapy by the secretion of IL 8 by dying cancer cells that signaled survival signals via the IL8 receptor, CXCR1, on the CSCs [48]. While our experiments examined cisplatin-resistant $\mathrm{ALDH}{ }^{\text {high }} \mathrm{CD} 44^{\text {high }}$ cells in vitro, it would be interesting to perform similar microarray experiments with HNSCC tumor xenografts in mice. Based on the substantial utilization of immune signaling pathways by HNCSC and the secretion of numerous cytokines, it is likely that cisplatin-resistant $\mathrm{HNCSC}$ in vivo would be more reliant on these immune signaling pathways.

A major goal of this work was to identify mechanisms/pathways utilized by cisplatin-resistant $\mathrm{ALDH}{ }^{\text {high }} \mathrm{CD} 44^{\text {high }}$ cells and therapeutically target those resistance pathways. It was beyond the scope of this work to investigate each immune signaling pathway. Future studies could focus on the role of TNF and/or IFN signaling in cisplatin-resistant $\mathrm{ALDH}^{\text {high }} \mathrm{CD} 44^{\text {high }}$ cells. There are FDAapproved therapies to block TNF, including Remicade (infliximab), Enbrel (etanercept), Humira (adalimumab), Cimzia (certolizumab pegol) and Simponi (golimumab). However, there are substantial risks with TNF inhibitors, including increased risk of development of solid cancers in patients with rheumatoid arthritis [49].

To focus efforts on rational therapeutic targeting of cisplatin-resistant $\mathrm{ALDH}^{\text {high }} \mathrm{CD} 44^{\text {high }}$ cells, we investigated FGF2 and EREG. The EGF family is well known to regulate HNSCC. HNSCC can express EGFR and expression is associated with worse outcome [7]. Various members of the EGF ligand family are secreted by HNSCC cells [27]. EREG is known to promote the proliferation of dental stem cells via the MAPK and JNK signaling pathways [28]. However, we failed to detect significant secretion of EREG protein following cisplatin treatment. Due to limited ELISA reagents, the EREG experiment was performed once with triplicate wells. This negative result may be due to EREG secretion being below detection levels in the ELISA. Based on the microarray mRNA data, it appears that EREG is more preferentially expressed by the $\mathrm{ALDH}{ }^{\text {high }} \mathrm{CD} 44^{\text {high }}$ cells compared to the $\mathrm{ALDH}^{\text {low }} \mathrm{CD} 44^{\text {low }}$, which constitute the majority of the cells in both UM-SCC-1 and UM-SCC-22B cell lines. Further experiments whereby $\mathrm{ALDH}{ }^{\text {high }} \mathrm{CD} 44^{\text {high }}$ and $\mathrm{ALDH}^{\text {low }} \mathrm{CD} 44^{\text {low }}$ cells are FACS sorted and treated separately in small micro-well plates may uncover a role of EREG secretion in cisplatin $\mathrm{ALDH}{ }^{\text {high }} \mathrm{CD} 44^{\text {high }}$ cells.

Based on the substantial secretion of FGF2 following cisplatin treatment of UM-SCC-1 and UM-SCC22B, we investigated whether inhibition of FGF signaling would target cisplatin-resistant $\mathrm{ALDH}^{\text {high }} \mathrm{CD} 44^{\text {high }}$ cells. The role of FGF signaling in HNSCC is poorly studied, but Nguyen et al. showed FGFR1 was highly expressed in $54 \%$ of HNSCC cases and was significantly correlated with malignant behavior [50]. Treatment of HNSCC lines with the FGFR inhibitor PD173074 reduced cell proliferation at low nanomolar concentrations [50]. However, PD173074 is not currently being tested in active clinical trials, which limits potential future studies.

Amongst the commercially available potent and selective FGFR inhibitors that are in clinical trials, we selected BGJ398 to investigate if FGFR inhibition targeted cisplatin-resistant $\mathrm{ALDH}{ }^{\text {high }} \mathrm{CD} 44^{\text {high }}$ cells. BGJ398, targets FGFR1, FGFR2, FGFR3, and FGFR4 and at nanomolar concentrations inhibits cell proliferation of $\mathrm{BaF} 3$ cells over expressing those receptors [32]. This inhibitor is currently in Phase II clinical trials for solid cancers, especially in patients with FGFR genetic alterations [33]. Guagnano et al. tested $18 \mathrm{HNSCC}$ cell lines and found that more than $8 \mu \mathrm{M}$ BGJ398 was needed to kill these cells when tested in 1536well plates [33]. This is in contrast to nanomolar inhibition of HNSCC cell proliferation by PD173074 [50].

Here, we determined the BGJ398 IC $_{50}$ concentration for UM-SCC-1 and UM-SCC-22B to be between $2-3.5 \mu \mathrm{M}$ depending on 3 or 5 -day treatment. This is above the plasma $\mathrm{C}_{\max }$ levels achieved in pre-clinical animal mouse models $(0.86 \mu \mathrm{M}-5 \mathrm{mg} / \mathrm{kg} \mathrm{IV} ; 0.42 \mu \mathrm{M}-$ $20 \mathrm{mg} / \mathrm{kg}$ oral gavage) or rat models $(0.97 \mu \mathrm{M}-5 \mathrm{mg} / \mathrm{kg}$ IV; $0.26 \mu \mathrm{M}-10 \mathrm{mg} / \mathrm{kg}$ oral gavage) [34]. Based on this information, we tested a range of BGJ398 doses from 1 to $5 \mu \mathrm{M}$ for the ability to target cisplatin-resistant ALDH ${ }^{\text {high }}{ }^{2 D} 44^{\text {high }}$ cells. Surprisingly, BGJ398 was able to reduce UM-SCC-1 ALDH ${ }^{\text {high }} \mathrm{CD} 44^{\text {high }}$ cells as a single agent at 2-4 $\mu \mathrm{M}$, which might be due to the low basal FGF2 secretion by UM-SCC-1 cells. In UM-SCC-22B cells, BGJ398 dramatically reduced cisplatin-resistant $\mathrm{ALDH}^{\text {high }} \mathrm{CD} 44^{\text {high }}$ cells at $1-2 \mu \mathrm{M}$, but had no effect as a single agent. This reduction at doses near the preclinical $\mathrm{C}_{\text {max }}$ suggests that BGJ398 might be able to target cisplatin-resistant $\mathrm{ALDH}{ }^{\text {high }} \mathrm{CD} 44^{\text {high }}$ cells in animal models. Furthermore, UM-SCC-22B was developed from a neck metastasis derived from a patient who had a primary tumor in the hypopharynx [51]. Since HNCSCs are predicted to mediate metastasis, the combination of cisplatin and BGJ398 might reduce the primary tumor burden and metastatic spread of UM-SCC-22B cells in animal models.

In conclusion, microarray analysis of HNCSCs from control and cisplatin-treated cells showed an enrichment of major signaling pathways, such as IFN, TNF, IL6/STAT, and $\mathrm{NF}-\mathrm{kB}$, in cisplatin-resistant $\mathrm{ALDH}{ }^{\text {high }} \mathrm{CD} 44^{\text {high }}$ cells. We demonstrated an increase in cytokine secretion by 
ELISA following cisplatin treatment. Microarray analysis showed FGF2 and EREG mRNA increased in cisplatin ALDH ${ }^{\text {high }} \mathrm{CD} 44^{\text {high }}$ cells. We found a substantial increase in FGF2 secretion following cisplatin treatment, but no statistical increase in EREG secretion. Finally, treatment of HNSCC cells with the FGFR inhibitor BGJ398 and cisplatin was able to reduce $\mathrm{ALDH}{ }^{\text {high }} \mathrm{CD} 44^{\text {high }}$ cells in the UM-SCC-22B cell line at low micromolar levels. As a single agent, BGJ398 reduced $\mathrm{ALDH}{ }^{\text {high }} \mathrm{CD} 44^{\text {high }}$ cells in the UM-SCC-1 cell line. The in vitro work presented here was informed by in vivo experiments that demonstrated that cisplatin treatment increases the fraction of head and neck cancer stem cells [21]. In search for a mechanistic explanation for these findings, we unveiled a significant role for FGFR signaling in the development of cisplatin resistance. Collectively, these data suggest that patients with head and neck cancer might benefit from targeting of cisplatin-resistant $\mathrm{ALDH} \mathrm{H}^{\text {high }} \mathrm{CD} 44^{\text {high }}$ cells by therapeutic inhibition of FGFR.

\section{MATERIALS AND METHODS}

\section{Reagents}

6-well (3516), 96-well tissue culture (3596), 96-well round bottom (3799), T75 (430641) flasks, and 35 um filter cap FACS tubes (352235) were from Corning. DMEM (11960), Penicillin-Streptomycin (15070, $5000 \mathrm{U} / \mathrm{mL})$, Glutamax (100X, 35050-061), Sodium Pyruvate (11360, $100 \mathrm{mM}$ ), and $0.25 \%$ trypsin/1 mM EDTA (25200) were from Invitrogen. Fetal Bovine Serum (SH30396.03) was from Hyclone. AO/PI (F23001) and Luna (L12002) slides were from Logos Biosystems. CD44-APC (clone G44-26; \#559942) was from BD Biosciences. DMSO (D2650), resazurin (R7017), and DAPI (D8417) were from Sigma. EREG ELISA (SEB945HU) was from Cedarlane. RNeasy Mini Kit (74106) was from Qiagen. RNA 6000 Pico and Nano Kits were from Agilent. Ovation Pico WTA System Kit was from NuGEN. Human Gene ST 2.1 microarrays were from Affymetrix. Clinical-grade cisplatin (Teva Pharmaceuticals; $1 \mathrm{mg} / \mathrm{mL}$ ) was obtained from University of Michigan Hospital Pharmacy. BGJ398 (S2183) was from Selleckchem and dissolved in DMSO to $1.78 \mathrm{mM}$. DEAB (01705) and Aldefluor Assay Buffer (01702) were from StemCell Technologies. Aldefluor reagent, BAAADA, was synthesized by the University of Michigan Vahlteich Medicinal Chemistry Core.

\section{Cell culture}

UM-SCC-1 and UM-SCC-22B cells [51] (gift from Thomas Carey) were cultured in DMEM/10\% FBS/1\% PenStrep/3X Glutamax/1 mM Sodium Pyruvate and plated at 2,500 cells $/ \mathrm{cm}^{2}$ in T75 flasks. Cells were passaged every 3-4 days and counted using the Luna FL cell counter with AO/PI dye.

\section{Alamar blue (resazurin) assay}

Resazurin powder was dissolved in PBS at $8 \mathrm{mM}$ and filtered. It was further diluted to $440 \mu \mathrm{M}$ with PBS and filtered [52].

$\mathrm{IC}_{50}$

1,000 UM-SCC-1 or 2,000 UM-SCC-22B cells [51] were seeded per well in $95 \mu \mathrm{L}$ of media in 96-well tissue culture plates. Drugs were diluted with media and $5 \mu \mathrm{L}$ transferred to $95 \mu \mathrm{L}$ of cells/media. Cell growth, based on mitochondrial redox potential, was measured at various time points using the Alamar Blue (resazurin) assay. $10 \mu \mathrm{L}$ $(\sim 10 \% \mathrm{vol} / \mathrm{vol})$ of $440 \mu \mathrm{M}$ resazurin was added to each well and incubated for $1-4 \mathrm{hrs}$ at $37^{\circ} \mathrm{C}$. Fluorescence, as a measure of cell growth, was measured with a BioTek Synergy plate reader by exciting at $530 \mathrm{~nm}$ and reading emission at $590 \mathrm{~nm}$. Fluorescence was normalized to $0 \%$ with wells without media and to $100 \%$ with wells containing untreated cells. Data was normalized and curve fitted using Prism 6. Curves were fitted using non-linear regression based on the formula:

$$
Y=\text { Bottom }+\frac{\text { Top }- \text { Bottom }}{1+\left(X / E C_{50}\right)^{- \text {Hill coefficient }}} .
$$

\section{ELISA}

50,000 cells were seeded in $2 \mathrm{~mL}$ media in triplicate wells in 6-well plates $\left(\sim 5,000\right.$ cells $\left./ \mathrm{cm}^{2}\right)$. The following day (Day 1), media was replaced with fresh media containing $2 \mu \mathrm{M}$ cisplatin. Media was replaced on days 3 and 5. On day $6,1000 \mu \mathrm{L}$ media was centrifuged at $2000 \mathrm{~g}$ for $5 \mathrm{~min}$ at $4^{\circ} \mathrm{C}$ to pellet cells. $200 \mu \mathrm{L}$ of media was transferred to round-bottom 96-well plates. ELISAs were performed according to manufacturer instructions at the University of Michigan Cancer Center ELISA Core.

\section{Flow cytometry}

50,000 UM-SCC-22B cells were plated in 12 wells in $2 \mathrm{~mL}$ media in two 6-well plates. The following day, media was replaced with fresh media with or without $2 \mu \mathrm{M}$ cisplatin. Media was replaced on days 3 and 5. On day 6 , cells were harvested with $0.25 \%$ trypsin, counted, filtered through $35 \mu \mathrm{m}$ membranes into $5 \mathrm{~mL}$ FACS tubes, and centrifuged at $337 \mathrm{~g}$ for $5 \mathrm{~min}$ at $4 \mathrm{C}$. Cell pellets were suspended in $985 \mu \mathrm{L}$ Aldefluor Assay Buffer. $10 \mu \mathrm{L}$ of 0.1 $\mathrm{mg} / \mathrm{mL}$ DAPI was added. $5 \mu \mathrm{L}$ of DEAB, as an inhibitor of the Aldefluor reaction, was added to a separate $5 \mathrm{~mL}$ FACS tube. $5 \mu \mathrm{L}$ of activated Aldefluor reagent was added to $995 \mu \mathrm{L}$ of cells/DAPI. $500 \mu \mathrm{L}$ of this solution was immediately transferred to the tube containing DEAB. Cells were incubated for $30 \mathrm{~min}$ at $37^{\circ} \mathrm{C}$. Tubes were centrifuged at $337 \mathrm{~g}$ for $5 \mathrm{~min}$ at $4^{\circ} \mathrm{C}$ and placed on ice. 
Cell pellets were suspended in $300 \mu \mathrm{L}$ Aldefluor Assay Buffer. $0.5 \mu \mathrm{L}$ CD44-APC was added to tubes, except the DEAB control tube. Samples were incubated for exactly $15 \mathrm{~min}$ on ice and then centrifuged. Cell pellets were suspended on ice in Aldefluor assay buffer for a final concentration of $1-3 \times 10^{6}$ cells $/ \mathrm{mL}$. Flow cytometry sorting was performed on a Beckman Coulter MoFlo XDP with $355 \mathrm{~nm}, 488 \mathrm{~nm}$, and $633 \mathrm{~nm}$ lasers with appropriate filters. Gating for CD44 $4^{\text {high }}$ and $\mathrm{ALDH}{ }^{\text {high }}$ events were determined using the DEAB sample as a fluorescence minus one control. Gates for $\mathrm{CD} 44^{\text {high }}$ and $\mathrm{ALDH}^{\text {high }}$ cells were set at $0.1 \%$. ALDH ${ }^{\text {high }} \mathrm{CD} 44^{\text {high }}$ and $\mathrm{ALDH}{ }^{\text {low }} \mathrm{CD} 44^{\text {low }}$ cells from control and cisplatin groups were collected into separate $5 \mathrm{~mL}$ FACS tubes containing $1 \mathrm{~mL}$ of $\mathrm{PBS} / 3 \%$ FBS. For flow cytometry analysis, samples were run on a Beckman Coulter CyAn ADP with 405 nm, 488 nm, and $633 \mathrm{~nm}$ lasers with appropriate filters. Data for at least 10,000 live cells were collected per each sample.

\section{RNA extraction, microarray, bioinformatic analysis}

See Supplementary Materials and Methods for in depth description. The dataset (CEL files and ComBat intensity values) has been deposited in Gene Expression Omnibus (GEO; http:/www.ncbi.nlm.nih.gov/geo/) of the National Center for Biotechnology Information with accession number GSE72384.

\section{Western blots}

Whole cell lysates were prepared using NP-40 lysis buffer (1\% Nonidet P-40, 50 mM Tris-HCL, $\mathrm{pH} 7.4,10 \%$ glycerol, $2 \mathrm{mM} \mathrm{MgCl}$, and $200 \mathrm{mM} \mathrm{NaCl}$ ) containing protease inhibitors. UM-SCC-1 and UM-SCC-22B cells were treated with BJG389 at $0.5,1,2.5$, or $5 \mu \mathrm{M}$ concentrations for 24 hours. Proteins were resolved using 9\% SDS-PAGE. Membranes were probed using antibodies at 1:500 dilution against human FGFR2 (Santa Cruz Biotechnology; Santa Cruz, CA, USA) and at 1:1,000,000 dilution against human GAPDH (Chemicon International, Millipore; Temecula, CA). Primary antibodies were incubated overnight at $4^{\circ} \mathrm{C}$, while secondary antibodies were incubated for 2 hours at room temperature.

\section{Orospheres}

Orospheres were cultured in DMEM/F-12 (Invitrogen) supplemented with $10 \mathrm{ng} / \mathrm{ml}$ EGF (Sigma-Millipore), 10ng/ml bFGF (Millipore), 1\% penicillin/streptomycin (Invitrogen), 1\% glutamax (Invitrogen), 1\% N-2 supplement (Invitrogen), as we described [53]. Unsorted UM-SCC-1 or UM-SCC-22B cells were counted using a hemocytometer, diluted to 12,000 single cells per $1.5 \mathrm{ml}$ of orosphere media, and added to 6-well ultra-low attachment plates (Corning; Corning, NY, USA). Cells were treated with vehicle or
BJG389 (Selleckchem, USA) for 24 hours by adding $500 \mu \mathrm{L}$ of orosphere media gently on top of the wells for a final volume of $2 \mathrm{~mL}$. Colonies of 25 cells or more were considered orospheres and were counted after 4 days.

\section{Cell cycle analysis}

For cell cycle analysis, $4 \times 10^{5} \mathrm{UM}-\mathrm{SCC}-1$ or UMSCC-22B cells were plated in 6-well plates. The next day, cells were treated with either vehicle or BJG398 (Selleckchem, USA) for 24 hours. Both supernatant and adherent cells were harvested. Cells were then exposed to $0.1 \%$ sodium citrate, $0.1 \%$ Triton $\mathrm{X}-100,50 \mu \mathrm{g} / \mathrm{mL}$ propidium iodide (Sigma-Aldrich), and $100 \mu \mathrm{g} / \mathrm{mL}$ RNaseA. Flow cytometry was conducted in the University of Michigan Flow Cytometry Core (LSRFortessa; BD Biosciences). The percentage of cells in each cell-cycle phase was analyzed using FlowJo software (FlowJo, LLC; Ashland, Oregon, USA). Data was averaged from triplicates.

\section{FGFR2 silencing}

Second-generation shRNA lentiviral vectors and packaging plasmids were obtained from the University of Michigan Vector Core. HEK293T cells were used for lentiviral particle production. Cells were transiently co-transfected by the calcium phosphate method with lentiviral packaging vectors psPAX2, pMD2G and shRNA-FGFR2 or shRNA-scramble sequence control (shRNA-C). UM-SCC-1 and UM-SCC-22B cells were infected with the virus-containing supernatants in presence of $4 \mu \mathrm{g} / \mathrm{mL}$ polybrene and selected with $1 \mu \mathrm{g} / \mathrm{ml}$ puromycin (Sigma-Aldrich, St. Louis, Missouri, USA) for 2 weeks.

\section{Statistical analysis}

All experiments were performed in at least triplicate per group and repeated at least twice. Except for the bioinformatics analysis, statistical significance was determined in Prism 6 using one-way ANOVA with Sidak's or Tukey's adjustment for multiple comparisons. Adjusted $p$-values $<0.05$ were considered significant.

\section{Author contributions}

Conception and design: S.C. McDermott, C. Rodriguez-Ramirez, S.P. McDermott, M.S. Wicha, J.E. Nör; Development of methodology: S.C. McDermott, C. Rodriguez-Ramirez, S.P. McDermott, J.E. Nör; Acquisition of data: S.C. McDermott, C. Rodriguez-Ramirez, S.P. McDermott, J.E. Nör; Analysis/interpretation of data: S.C. McDermott, C. Rodriguez-Ramirez, S.P. McDermott, M.S. Wicha, J.E. Nör; Writing, review, and/or revision of the 
manuscript: S.C. McDermott, C. Rodriguez-Ramirez, S.P. McDermott, M.S. Wicha, J.E. Nör; Administrative, technical, or material support: S.C. McDermott, S.P. McDermott, M.S. Wicha, J.E. Nör; Study supervision: S.P. McDermott, M.S. Wicha, J.E. Nör.

\section{ACKNOWLEDGMENTS AND FUNDING}

We thank Dr. Thomas Carey for generous gift of the HNSCC cell lines used here. This work was funded by a grant from the Delta Dental Foundation (SCM); University of Michigan Head Neck SPORE P50-CA97248 from the NIH/NCI; grants R01-DE23220, R01-DE21139 from the NIH/NIDCR (JEN).

\section{CONFLICTS OF INTEREST}

The authors have declared that no competing interests exist.

\section{REFERENCES}

1. Bonnet D, Dick JE. Human acute myeloid leukemia is organized as a hierarchy that originates from a primitive hematopoietic cell. Nat Med. 1997; 3:730-737.

2. O'Brien CA, Pollett A, Gallinger S, Dick JE. A human colon cancer cell capable of initiating tumour growth in immunodeficient mice. Nature. 2007; 445:106-10.

3. Singh SK, Hawkins C, Clarke ID, Squire JA, Bayani J, Hide T, Henkelman RM, Cusimano MD, Dirks PB. Identification of human brain tumour initiating cells. Nature. 2004; 432:396-401.

4. Prince ME, Sivanandan R, Kaczorowski A, Wolf GT, Kaplan MJ, Dalerba P, Weissman IL, Clarke MF, Ailles LE. Identification of a subpopulation of cells with cancer stem cell properties in head and neck squamous cell carcinoma. Proc Natl Acad Sci USA. 2007; 104:973-978.

5. Siegel RL, Miller KD, Jemal A. Cancer statistics, 2015. CA Cancer J Clin. 2015; 65:5-29.

6. Price KA, Cohen EE. Current treatment options for metastatic head and neck cancer. Curr Treat Options Oncol. 2012; 13:35-46.

7. Temam S, Kawaguchi H, El-Naggar AK, Jelinek J, Tang H, Liu DD, Lang W, Issa JP, Lee JJ, Mao L. Epidermal growth factor receptor copy number alterations correlate with poor clinical outcome in patients with head and neck squamous cancer. J Clin Oncol. 2007; 25:2164-2170.

8. Li S, Schmitz KR, Jeffrey PD, Wiltzius JJ, Kussie P, Ferguson KM. Structural basis for inhibition of the epidermal growth factor receptor by cetuximab. Cancer Cell. 2005; 7:301-311.

9. Kimura H, Sakai K, Arao T, Shimoyama T, Tamura T, Nishio K. Antibody-dependent cellular cytotoxicity of cetuximab against tumor cells with wild-type or mutant epidermal growth factor receptor. Cancer Sci. 2007; 98:1275-1280.

10. Vermorken JB, Mesia R, Rivera F, Remenar E, Kawecki A, Rottey S, Erfan J, Zabolotnyy D, Kienzer HR, Cupissol D, Peyrade F, Benasso M, Vynnychenko I, et al. Platinumbased chemotherapy plus cetuximab in head and neck cancer. N Engl J Med. 2008; 359:1116-1127.

11. Dick JE. Stem cell concepts renew cancer research. Blood. 2008; 112:4793-4807.

12. Reya T, Morrison SJ, Clarke MF, Weissman IL. Stem cells, cancer, and cancer stem cells. Nature. 2001; 414:105-111.

13. Joshua B, Kaplan MJ, Doweck I, Pai R, Weissman IL, Prince ME, Ailles LE. Frequency of cells expressing CD44, a head and neck cancer stem cell marker: correlation with tumor aggressiveness. Head Neck. 2012; 34:42-49.

14. Wei XD, Zhou L, Cheng L, Tian J, Jiang JJ, Maccallum J. In vivo investigation of CD133 as a putative marker of cancer stem cells in Hep-2 cell line. Head Neck. 2009; 31:94-101

15. Clay MR, Tabor M, Owen JH, Carey TE, Bradford CR, Wolf GT, Wicha MS, Prince ME. Single-marker identification of head and neck squamous cell carcinoma cancer stem cells with aldehyde dehydrogenase. Head Neck. 2010; 32:1195-1201.

16. Chen YC, Chen YW, Hsu HS, Tseng LM, Huang PI, Lu KH, Chen DT, Tai LK, Yung MC, Chang SC, Ku HH, Chiou $\mathrm{SH}$, Lo WL. Aldehyde dehydrogenase 1 is a putative marker for cancer stem cells in head and neck squamous cancer. Biochem Biophys Res Commun. 2009; 385:307-313.

17. Krishnamurthy S, Dong Z, Vodopyanov D, Imai A, Helman JI, Prince ME, Wicha MS, Nor JE. Endothelial cellinitiated signaling promotes the survival and self-renewal of cancer stem cells. Cancer Res. 2010; 70:9969-9978.

18. Krishnamurthy S, Warner KA, Dong Z, Imai A, Nor C, Ward BB, Helman JI, Taichman RS, Bellile EL, McCauley LK, Polverini PJ, Prince ME, Wicha MS, et al. Endothelial interleukin- 6 defines the tumorigenic potential of primary human cancer stem cells. Stem Cells. 2014; 32:2845-2857.

19. Davis SJ, Divi V, Owen JH, Bradford CR, Carey TE, Papagerakis S, Prince ME. Metastatic potential of cancer stem cells in head and neck squamous cell carcinoma. Arch Otolaryngol Head Neck Surg. 2010; 136:1260-1266.

20. Tabor MH, Clay MR, Owen JH, Bradford CR, Carey TE, Wolf GT, Prince ME. Head and neck cancer stem cells: the side population. Laryngoscope. 2011; 121:527-533.

21. Nor C, Zhang Z, Warner KA, Bernardi L, Visioli F, Helman JI, Roesler R, Nor JE. Cisplatin induces Bmi-1 and enhances the stem cell fraction in head and neck cancer. Neoplasia. 2014; 16:137-146.

22. Johnson WE, Li C, Rabinovic A. Adjusting batch effects in microarray expression data using empirical Bayes methods. Biostatistics. 2007; 8:118-127.

23. Subramanian A, Tamayo P, Mootha VK, Mukherjee S, Ebert BL, Gillette MA, Paulovich A, Pomeroy SL, Golub TR, 
Lander ES, Mesirov JP. Gene set enrichment analysis: a knowledge-based approach for interpreting genomewide expression profiles. Proc Natl Acad Sci U S A. 2005; 102:15545-15550.

24. Donato $\mathrm{M}, \mathrm{Xu} \mathrm{Z}$, Tomoiaga A, Granneman JG, Mackenzie RG, Bao R, Than NG, Westfall PH, Romero R, Draghici S. Analysis and correction of crosstalk effects in pathway analysis. Genome Res. 2013; 23:1885-1893.

25. Draghici S, Khatri P, Tarca AL, Amin K, Done A, Voichita C, Georgescu C, Romero R. A systems biology approach for pathway level analysis. Genome Res. 2007; 17:1537-1545.

26. Wilson KJ, Mill C, Lambert S, Buchman J, Wilson TR, Hernandez-Gordillo V, Gallo RM, Ades LM, Settleman J, Riese DJ. EGFR ligands exhibit functional differences in models of paracrine and autocrine signaling. Growth Factors. 2012; 30:107-116.

27. Oshima G, Wennerberg J, Yamatodani T, Kjellen E, Mineta H, Johnsson A, Ekblad L. Autocrine epidermal growth factor receptor ligand production and cetuximab response in head and neck squamous cell carcinoma cell lines. J Cancer Res Clin Oncol. 2012; 138:491-499.

28. Cao Y, Xia DS, Qi SR, Du J, Ma P, Wang SL, Fan ZP. Epiregulin can promote proliferation of stem cells from the dental apical papilla via MEK/Erk and JNK signalling pathways. Cell Prolif. 2013; 46:447-456.

29. Zhang Z, Dong Z, Lauxen IS, Filho MS, Nor JE. Endothelial cell-secreted EGF induces epithelial to mesenchymal transition and endows head and neck cancer cells with stemlike phenotype. Cancer Res. 2014; 74:2869-2881.

30. Eiselleova L, Matulka K, Kriz V, Kunova M, Schmidtova Z, Neradil J, Tichy B, Dvorakova D, Pospisilova S, Hampl A, Dvorak P. A complex role for FGF-2 in self-renewal, survival, and adhesion of human embryonic stem cells. Stem Cells. 2009; 27:1847-1857.

31. Marshall ME, Hinz TK, Kono SA, Singleton KR, Bichon B, Ware KE, Marek L, Frederick BA, Raben D, Heasley LE. Fibroblast growth factor receptors are components of autocrine signaling networks in head and neck squamous cell carcinoma cells. Clin Cancer Res. 2011; 17:5016-5025.

32. Guagnano V, Furet P, Spanka C, Bordas V, Le Douget M, Stamm C, Brueggen J, Jensen MR, Schnell C, Schmid H, Wartmann M, Berghausen J, Drueckes P, et al. Discovery of 3-(2,6-dichloro-3,5-dimethoxy-phenyl)-1-\{6-[4-(4-ethylpiperazin-1-yl)-phenylamin o]-pyrimidin-4-yl\}-1-methylurea (NVP-BGJ398), a potent and selective inhibitor of the fibroblast growth factor receptor family of receptor tyrosine kinase. J Med Chem. 2011; 54:7066-7083.

33. Guagnano V, Kauffmann A, Wöhrle S, Stamm C, Ito M, Barys L, Pornon A, Yao Y, Li F, Zhang Y, Chen Z, Wilson CJ, Bordas V, et al. FGFR genetic alterations predict for sensitivity to NVP-BGJ398, a selective pan-FGFR inhibitor. Cancer Discov. 2012; 2:1118-1133.

34. Michifuri Y, Hirohashi Y, Torigoe T, Miyazaki A, Fujino J, Tamura Y, Tsukahara T, Kanaseki T, Kobayashi J, Sasaki T, Takahashi A, Nakamori K, Yamaguchi A, et al. Small proline-rich protein-1B is overexpressed in human oral squamous cell cancer stem-like cells and is related to their growth through activation of MAP kinase signal. Biochem Biophys Res Commun. 2013; 439:96-102.

35. Lin L, Hutzen B, Lee HF, Peng Z, Wang W, Zhao C, Lin HJ, Sun D, Li PK, Li C, Korkaya H, Wicha MS, Lin J. Evaluation of STAT3 signaling in ALDH+ and ALDH+/ CD44+/CD24- subpopulations of breast cancer cells. PLoS One. 2013; 8:e82821.

36. Korkaya H, Kim GI, Davis A, Malik F, Henry NL, Ithimakin S, Quraishi AA, Tawakkol N, D'Angelo R, Paulson AK, Chung S, Luther T, Paholak HJ, et al. Activation of an IL6 Inflammatory Loop Mediates Trastuzumab Resistance in HER2+ Breast Cancer by Expanding the Cancer Stem Cell Population. Mol Cell. 2012; 47:570-584.

37. Zhang L, Jiao M, Wu K, Li L, Zhu G, Wang X, He D, Wu D. TNF-alpha induced epithelial mesenchymal transition increases stemness properties in renal cell carcinoma cells. Int J Clin Exp Med. 2014; 7:4951-4958.

38. Fillmore CM, Kuperwasser C. Human breast cancer cell lines contain stem-like cells that self-renew, give rise to phenotypically diverse progeny and survive chemotherapy. Breast Cancer Res. 2008; 10:R25.

39. Liu S, Cong Y, Wang D, Sun Y, Deng L, Liu Y, MartinTrevino R, Shang L, McDermott SP, Landis MD, Hong S, Adams A, D'Angelo R, et al. Breast Cancer Stem Cells Transition between Epithelial and Mesenchymal States Reflective of their Normal Counterparts. Stem Cell Reports. 2013; 2:78-91.

40. Mani SA, Guo W, Liao MJ, Eaton EN, Ayyanan A, Zhou AY, Brooks M, Reinhard F, Zhang CC, Shipitsin M, Campbell LL, Polyak K, Brisken C, et al. The epithelialmesenchymal transition generates cells with properties of stem cells. Cell. 2008; 133:704-715.

41. Kendellen MF, Bradford JW, Lawrence CL, Clark KS, Baldwin AS. Canonical and non-canonical NF-kappaB signaling promotes breast cancer tumor-initiating cells. Oncogene. 2014; 33:1297-305.

42. Murohashi M, Hinohara K, Kuroda M, Isagawa T, Tsuji S, Kobayashi S, Umezawa K, Tojo A, Aburatani H, Gotoh N. Gene set enrichment analysis provides insight into novel signalling pathways in breast cancer stem cells. Br J Cancer. 2010; 102:206-212.

43. Guzman ML, Rossi RM, Neelakantan S, Li X, Corbett CA, Hassane DC, Becker MW, Bennett JM, Sullivan E, Lachowicz JL, Vaughan A, Sweeney CJ, Matthews W, et al. An orally bioavailable parthenolide analog selectively eradicates acute myelogenous leukemia stem and progenitor cells. Blood. 2007; 110:4427-4435.

44. Gyanchandani R, Ortega Alves MV, Myers JN, Kim S. A proangiogenic signature is revealed in FGF-mediated bevacizumab-resistant head and neck squamous cell carcinoma. Mol Cancer Res. 2013; 11:1585-1596.

45. Conley SJ, Gheordunescu E, Kakarala P, Newman B, Korkaya H, Heath AN, Clouthier SG, Wicha MS. 
Antiangiogenic agents increase breast cancer stem cells via the generation of tumor hypoxia. Proc Natl Acad Sci USA. 2012; 109:2784-2789.

46. Muller A, Sonkoly E, Eulert C, Gerber PA, Kubitza R, Schirlau K, Franken-Kunkel P, Poremba C, Snyderman C, Klotz LO, Ruzicka T, Bier H, Zlotnik A, et al. Chemokine receptors in head and neck cancer: association with metastatic spread and regulation during chemotherapy. Int J Cancer. 2006; 118:2147-2157.

47. Wolff HA, Rolke D, Rave-Frank M, Schirmer M, Eicheler W, Doerfler A, Hille A, Hess CF, Matthias C, Rodel RM, Christiansen H. Analysis of chemokine and chemokine receptor expression in squamous cell carcinoma of the head and neck (SCCHN) cell lines. Radiat Environ Biophys. 2011; 50:145-154.

48. Ginestier C, Liu S, Diebel ME, Korkaya H, Luo M, Brown M, Wicinski J, Cabaud O, Charafe-Jauffret E, Birnbaum D, Guan JL, Dontu G, Wicha MS, et al. CXCR1 blockade selectively targets human breast cancer stem cells in vitro and in xenografts. J Clin Invest. 2010; 120:485-497.
49. Jain A, Singh JA. Harms of TNF inhibitors in rheumatic diseases: a focused review of the literature. Immunotherapy. 2013; 5:265-299.

50. Nguyen PT, Tsunematsu T, Yanagisawa S, Kudo Y, Miyauchi M, Kamata N, Takata T. The FGFR1 inhibitor PD173074 induces mesenchymal-epithelial transition through the transcription factor AP-1. Br J Cancer. 2013; 109:2248-2258.

51. Brenner JC, Graham MP, Kumar B, Saunders LM, Kupfer R, Lyons RH, Bradford CR, Carey TE. Genotyping of 73 UM-SCC head and neck squamous cell carcinoma cell lines. Head Neck. 2010; 32:417-426.

52. O'Brien J, Wilson I, Orton T, Pognan F. Investigation of the Alamar Blue (resazurin) fluorescent dye for the assessment of mammalian cell cytotoxicity. Eur J Biochem. 2000; 267:5421-5426.

53. Krishnamurthy S, Nör JE. Orosphere assay: a method for propagation of head and neck cancer stem cells. Head Neck. 2013; 35:1015-1021. 